\title{
Innovation and standardization as drivers of companies' success in public procurement: an empirical analysis
}

\author{
Knut Blind $^{1,2}$ (D) Jakob Pohlisch ${ }^{1}$ (D) Anne Rainville ${ }^{1,3,4}$ \\ Published online: 20 February 2019 \\ (c) The Author(s) 2019
}

\begin{abstract}
There is a significant potential to improve the benefits from public procurement through a better understanding of drivers in company success at the micro-level, an area that has received little study to date. To increase these impacts on innovation and markets, policy makers have opened procurement to innovation, including the strategic incorporation of formal standards in calls for tenders. Consequently, companies offering innovative solutions should have higher chances to be successful in public tenders. In addition, companies who engage in standardization activities at standards development organizations may have a competitive advantage in submitting tenders. Examining the case of Germany, this paper empirically investigates the effects of German manufacturing companies' innovation activities and their engagement in national standardization on the receipt of contracts within domestic procurement competitions. The results of our empirical analyses based on German companies surveyed within the framework of the Community Innovation Survey show that being successful in product innovation and being engaged in standardization are significant positive predictors of companies' success in public procurement. With implications for policy-makers and practitioners, this shows that public procurement is indeed open for solutions from companies active in innovation and standardization.
\end{abstract}

Keywords Public procurement · Innovation - Standardization · Company strategy · Competitiveness

JEL Classification $\mathrm{O} 30 \cdot \mathrm{H} 57 \cdot \mathrm{L} 15 \cdot \mathrm{L} 60$

Knut Blind

Knut.Blind@TU-Berlin.de

1 Chair of Innovation Economics, Faculty of Economics and Management, Technische Universität Berlin, MAR 2-5, Marchstraße 23, 10587 Berlin, Germany

2 Fraunhofer Institute for Open Communication Systems, Kaiserin-Augusta-Allee 31, 10589 Berlin, Germany

3 The Maastricht School of Management, Endepolsdomein 150, 6229 EP Maastricht, The Netherlands

4 Vtrek B.V., Julianaplein 21, 5211 BB 's-Hertogenbosch, The Netherlands 


\section{Introduction}

For decades, innovation policy has focused on supporting the generation of innovations. Recently, increasing attention has been paid to the demand conditions for innovation and consequently demand-side innovation policy (Edler 2016). In addition to the support for private demand, public demand, i.e. public procurement, has gained significant attraction as innovation policy instrument both among policy makers and academics (Uyarra 2016) due to the larger purchasing and signaling power that the government has as a lead user (OECD 2011). Policy makers have opened public procurement to innovation (EC 2014) to increase the impacts of public purchasing on innovation. Moving beyond improving public service provision, public procurement which stimulates the generation of new ideas and facilitates their translation into innovation has impacts at the firm level and subsequent macro-level benefits (EC 2014, p. 72).

The strategic incorporation of standards in calls for tenders can increase these innovation impacts (EC 2008; Blind 2008; Koch and Jacobsen 2014) by opening competition to potential suppliers and ideas. Applying standards in technical specifications or award criteria dictates the necessary characteristics of a product or service to be purchased, as well as additional features upon which the evaluation can be based. The ability for a company to meet these requirements and criteria influence their competitiveness toward winning a given public contract. Due to the increasing prominence of standards in calls for tenders (Europe Innova 2008) a company's competitive advantage in receiving such contracts and reaping associated benefits will be partially dependent on their awareness of and ability to deploy standards. As such, companies engaged in standards development organizations (SDOs) "standardizing companies"-may be more competitive in such competitions. Their advantage may enforce the challenges for small and less innovative companies in receiving contracts, as these companies face particular barriers to public procurement (Uyarra et al. 2014) and are less likely to be engaged in standardization activities (Blind 2006; Blind and Mangelsdorf 2013; Wakke et al. 2015). It follows that, if the policy to open procurement to innovation is successful, then firms with more engagement in innovation and standardization may have a higher likelihood of receiving public procurement contracts. Examining the case of Germany, this paper investigates the effects of company innovation activities and the engagement in national standardization on the receipt of contracts from public procurement competitions. According to the OECD (2018), Germany has considered the interests of SMEs in public procurement for a long time by facilitating their access to public procurement. Contracting authorities have to ensure a level playing field, e.g. by dividing public contracts into smaller lots. Consequently, SMEs are awarded around $70 \%$ of public contracts and two thirds of the contract value. In addition, policies and strategies, especially those on innovation in public procurement, take SMEs into consideration. For example, a competence centre was created to help contracting authorities put the policy goal of furthering innovation through public procurement and procuring innovative goods and services into practice-including best practice examples and advices on concrete practical questions.

Timing and openness in standardization are critical for it to effectively support and not hinder innovation in general (David 1995; Maxwell 1998; Cabral and Salant 2014) and through public procurement in particular (Dale and Bryson 2012). Standards are 'major elements of demand-based policies' (Edler et al. 2014, p. 37), which help to create demand and aide diffusion of innovations (OECD 2009). Along with public procurement, standardization can serve to 'facilitate market entry or facilitate the diffusion of innovations in the case of market failure' (OECD 2011, p. 11), and both are an integral part of Germany's High-Tech strategy for promoting diffusion of innovations (BMBF 2006, 2010, 2014). However, this potential does not 
often manifest. For example, an "Innovation Union" communication regards 'slow standardisation and ineffective use of public procurement' (EC 2010, p. 2) as deterrents to innovation.

Standardization with respect to public procurement has been previously discussed by focusing on process homogenization across purchasing agencies, rather than the creation of formal standards at an SDO. For example, recent literature has touched upon the standardization of procurement processes and suggests common tenders across instances and institutions (e.g. Loader 2013, 2015; Malara and Mazurkiewicz 2012). In Germany, standardization across the country's procurement landscape has been called for in terms of a central procurement platform and for harmonizing procurement law (Wegweiser et al. 2009). Discussions of this nature are also associated with the incorporation of formal standards. For European-wide competitions, standards such as those for quality and the environment should be chosen through administrative cooperation across borders (EC 2014). This cooperation would support knowledge sharing on performance-based specification development (Rigby et al. 2012), as a form of standardization on behalf of public agencies, and help to address the fragmentation across European markets (Edler et al. 2014).

Research on standardization at SDOs, which create many standards that are also relevant to public procurement, is largely absent from the public procurement literature. Further, the potential connection between firm involvement in standardization and success in procurement has yet to be investigated. Despite the growing importance of the link between innovation and public procurement, the research is challenged by missing or incomplete data, especially to test for causal relationships (Appelt and Galindo-Rueda 2016). Besides these general research gaps, no research has looked both at the innovativeness of companies and their involvement in standardization as a specific form of open innovation strategy as potential success factors in the receipt of procurement contracts. Applying definitions of Chesbrough (2004), engagement in standardization is a form of outbound open innovation, where technical information is revealed, but is also a source for inbound open innovation where companies learn from each other.

Despite the policy objective to promote innovation via public procurement, there is still large-scale evidence missing, whether in innovative companies are in a better position to succeed in public procurement. The link between standardization and public procurement has not at all been empirically investigated. Based on these research gaps, our analysis will answer the following two research questions based on companies as unit of analysis, like Georghiou et al. (2014), but in contrast to public procurement projects (Yeow and Edler 2012) or public procurers (Rainville 2016):

1. Are more innovative companies more successful in winning public procurement contracts?

2. Are companies active in standardization more successful in winning public procurement contracts?

At first, our study contributes to the literature by confirming explicitly the important role of companies' innovativeness for the public procurement of innovation. Secondly, we provide the first empirical evidence for a positive association between companies' participation in standardization and their success in public procurement. 


\section{Literature review and derivation of hypotheses}

Public purchasers often apply cost, but sometimes also innovation criteria towards determining the Most Economically Advantageous Tender (MEAT). In designing and awarding tenders, public purchasers use standards in program requirements to guarantee minimum quality and support low costs. Innovation can be required in technical specifications or rewarded in award criteria in different ways, such that potential suppliers which can provide a desired innovation at a low cost are more competitive. In the following section we review relevant literature to provide a background to the dimensions of innovation and standardization, complemented by additional company characteristics examined in this paper. Eventually, two hypotheses are derived.

\subsection{Innovation}

Literature has supported the effects of public procurement on company and market innovations (Ghisetti 2017), comparing public procurement with other demand-side (Geroski 1990) or supply-side measures (Aschhoff and Sofka 2009; Guerzoni and Raiteri 2015). However, Pickernell et al. (2011) identify public financing as positively and significantly associated with receipt of local public procurement contracts for small and medium-sized companies (SMEs).

Contextualizing public procurement amongst private measures, public buyers are only second to market changes as a source for company innovation, but more influential than internal R\&D expenditure or private buyers (Georghiou et al. 2014). Through receiving public contracts, approximately half of the companies engaged in procurement in the United Kingdom increased their R\&D expenditures, and two thirds noted that doing so influenced their innovation activities (Georghiou et al. 2014). Similarly, R\&D-intensive companies identified specifications that were too prescriptive, and contracts that were too small, to be major barriers for innovation (Uyarra et al. 2014) as these did not invite more ideas and could not support the necessary innovation activities required.

In comparison, there has been a limited number of studies about the influence of innovation factors at the company level on their success in receiving public procurement contracts. In the study by Georghiou et al. (2014), 56\% of firms report that they had won a public-sector contract 'because of innovation' (p. 7), suggesting that company innovation or potential to deliver innovation is a success factor for many companies receiving public procurement contracts. Others find $\mathrm{R} \& \mathrm{D}$ spending and the holding of intellectual property to be a significant factor influencing a company's accessibility to procurement competitionsparticularly for SMEs for tenders from above the local municipal level, such as those by government agencies and EU central government (Pickernell et al. 2011). Thus, given that company innovation or innovation potential seems to be associated with access to procurements from public agencies, we expect a positive relationship between innovation measures and the receipt of public procurement contracts. The size of the effect may be dampened if fewer innovative companies pursue public contracts, due the lower extend of competition.

Based on the findings above it becomes clear that the direction of the effect is not clear at this point. Do more innovative companies have a higher likelihood of winning procurement contracts or are companies being more innovative as a consequence of receiving public procurement contracts. We argue that both directions are likely to be true. However, the majority of studies have been concentrating on the latter directions. Thus, our paper addresses the former 
direction. To address the present endogeneity problem - a problem faced by all previous studies which are solely based on cross sectional data-we apply a regression framework that incorporates instrumental variables. To our knowledge our contribution is the first to do so.

Based on the above, the following hypothesis is derived:

H1: There exists a positive association between companies' innovativeness and their likelihood to receive public procurement contracts.

\subsection{Standardization}

Whereas regulations are enacted by the government through a top-down approach, formal standards are mostly the result of a market-driven process (Büthe and Mattli 2011) — or as Gupta and Lad (1983) call it-industry self-regulation. According to the definition of the European Commission (EC 2008, p. 2), standardization is the voluntary development of 'technical specifications based on consensus amongst the interested parties', including industry, relevant interest groups, and public authorities. It results in the publication of voluntary standards, available to the public (for free or for a cost). Engagement in standardization, while itself dependent upon the availability of a company's resources, is highly influenced by a company's ability to understand the benefits of standards and to be able to deploy them in strategic applications that influence competitiveness (Blind and Mangelsdorf 2016).

\subsection{Use of standards in procurement}

In public procurement, agencies may use a variety of types of standards, technical specifications, or eco-labels if they are based on 'scientific information using a procedure in which stakeholders, such as government bodies, consumers, manufacturers, distributors and environmental organizations can participate' (EC 2004, p. 7). The updated European Directive cites national standards transposing European standards as the most preferable source for technical specifications, for application 'without prejudice to mandatory national technical rules' (EC 2014, p. 121). Procurers have the option to use standards as performance or functional requirements. Referenced standards could be at the domestic level if no European standard is available (EC 2014).

Including appropriate standards supports openness in calls for tenders (DIN 2014), enabling fairer competition that is open to more bidders and innovative solutions (EC 2004). Including performance or functional requirements as minimum standards-rather than very narrowly defined technical specifications - is encouraged as it is in general more efficient (e.g. Besanko 1987) and ensures this openness (Hommen and Rolfstam 2009; EC 2014). ${ }^{1}$ For example, in the case of procuring waste management, very restrictive standards can lead to a rather low numbers of bids (Arvidsson and Stage 2012). ${ }^{2}$ Regarding tenders received, procurers should not discriminate between submitted tenders that meet minimum requirements based on equivalent domestic, European, or international standards so long as these specifications address the requirements stated in the call for tenders (EC 2014).

\footnotetext{
${ }^{1}$ Only if the regulator is sufficiently well informed about the technological possibilities (Hueth and Melkonyan 2009), design standards can improve welfare.

2 In addition, Ghosh's (2005) analysis of public tenders in the area of information technology reveals that public procurers include references to specific proprietary de facto standards, another form of overspecification, which generates challenges for all competitors, especially small and medium sized companies.
} 
Similar to how awareness of rules and regulations can be a factor for a successful public procurement (Tabish and Jha 2011), awareness of existing voluntary standards cited in calls for tenders may improve the likelihood of receiving public procurement contracts.

While also beneficial for cost-competitiveness in markets, the use of standards in public procurement competitions helps purchasers to meet requirements of low cost. By also guaranteeing a minimum quality, the risk-reducing effects of standards compensate for the risk adverse attitudes of public purchasers. The same is true for using well established compatibility standards, especially in procurement of information and communication technologies (David and Greenstein 1990). As such, use of and benefits from standards in public procurement should be amplified when compared with private markets.

Whereas Blind and Gauch (2009) attribute the various functions of standards to the phases of the R\&D process, Hommen and Rolfstam (2009) position standards within their typology of public procurement-according to organizational and evolutionary considerations. In direct procurement where procurers purchase for their own organization, standards are used in the transitory stage of market evolution to improve standard solutions established by the market players. One example is the role of Finnish public telecom operator (PTO), as a competent technology procurer, in the development of the first-generation cellular standard, the NMT-standard in collaboration with Nokia (Palmberg 2002). In cooperative and catalytic procurement, where purchasers work with one another or purchase for a separate end-user, standards come into play in the late stage of market evolution, i.e. in the consolidation phase (Rolfstam 2013). In catalytic procurement, Rigby et al. (2012) call for further investigation into standards development for the end-user of the product that is procured. In cooperative procurement, the public procurers develop and define product standards, because the 'producer domination' typical for technologies and industries in late stages of development can be counteracted through standards development processes that insure wide user inclusion. Finally, during catalytic public procurement, procuring agencies typically take on the role of setting performance standards and testing for product approval. Key modes of intervention include labeling and official endorsement for which only products meeting certain standards can be used (e.g. Neij 2001, regarding standards as ex-post measures which support transformations towards energy-efficient products and services).

Regarding standard type, Blind et al. (2010) found standards published by formal standardization bodies to have the strongest positive effects when compared to informal consortia or proprietary standards. ${ }^{3}$ For the ICT sector, such standards had the greatest impacts on (1) development, procurement, and combination of products/services; (2) global industry structures/markets; and (3) economic impacts (mostly cost and price-related) at the firm and industry level (Blind et al. 2010). As such, the required openness and non-proprietary character of formal standards can maximize the potential of public procurement for promoting innovation, especially of those at the international level (Blind 2008). Engagement at SDOs that produce such formal standards can instill greater credibility than other standards setting processes that are closed or proprietary (Rainville et al. 2014), and may have proportionately large impacts on public procurement outcomes that is worthy of study.

\subsection{Development of standards}

As mentioned earlier, the empirical relationship between standardization and public procurement has not been examined comprehensively. With $41 \%$ of calls for tenders citing

\footnotetext{
${ }^{3}$ For a discussion of the limitation of referencing consortia standards in public procurement, see EC (2011).
} 
formal open standards (Europe Innova 2008), engagement in standardization may increase the competitiveness of suppliers submitting tenders. Company engagement in standardization can be predicted by a number of factors, including a company's size, export intensity, and economic sector. An inverted U-shape characterizes relationships between standardization and company size-i.e., companies who are engaged in standardization tend to be those within a middle range and not on the large or small ends of the spectrum (Blind 2006). Very small companies may lack resources and absorptive capacity to benefit from knowledge spillovers associated with standardization, and very large companies may not sufficiently benefit from knowledge-sharing activities to increase already large market shares (Blind 2006; Blind and Mangelsdorf 2013; Wakke et al. 2015). Wakke et al. (2016) show that German companies' involvement in standardization increases their productivity and performance. The extent to which this factor can predict success in public procurement may also depend on the type of procurement, such as those, which have higher likelihoods of using standards as references. These are namely procurements of a greater number of products, with higher financial values, longer product life cycles, and/or with a greater frequency of similar/identical procurement processes (Blind 2007).

Procuring agencies may also be involved in standardization, as another form of interaction with companies regarding innovation, among other mechanisms including joint purchasing, public-private procurement partnerships, and pre-commercial procurement. However, less than half of public institutions report any degree of this engagement (Wegweiser et al. 2009). In theory, R\&D results from pre-commercial procurement could be disseminated by public bodies through standardization (EC 2007), but this has only been realized in exceptional cases. In Germany, co-operation of procuring institutions with standardization bodies is neither common nor intensive, with $25 \%$ of organizations reporting some degree of engagement and only $3 \%$ of this being intensive or very intensive (Wegweiser et al. 2009). For DIN SPECS - a process suitable for intercompany standards required relatively quickly, such as in the early stages of innovation-this percentage decreases to $2 \%$ (DIN 2013). In contrast, engagement of procuring agencies with other departments, the users of the product or service to be procured, and other procurement offices are much higher, at over $80 \%$. Thus, the potential for reverse causality, i.e. the impact of public procurement on standardization in our analysis is rather low. While firms submitting tenders to public procurement contracts may not meet those from the public agencies making direct purchasing decisions, they have opportunities to meet other potential stakeholders from whom they could glean useful information into how to increase their competitiveness in public purchases.

Based on the previous arguments, engagement in standardization is not only enhancing companies performance (Wakke et al. 2016), but expected to increase the likelihood of success in domestic-level public procurement. Since companies who do so are more likely to (a) use standards referenced by calls for tenders already (i.e., independently or prior to the call) and (b) have been partly influential in creating those standards that are referenced, as involvement in standardization is a company strategy to influence its outcome (Weiss and Sirbu 1990); and (c) in rare instances companies may meet public procurers in standardization processes (Wegweiser et al. 2009), the dialogue from which may assist companies in competing in calls for tenders (Uyarra et al. 2014).

Based on the above, the following hypothesis is derived:

H2: There exists a positive association between companies' engagement in standardization and their likelihood to receive public procurement contracts. 


\subsection{Company characteristics}

In addition to innovation and standardization factors that may influence the receipt of public procurement contracts, several company characteristics are of interest for their ability to influence procurement successes in a similar manner.

\subsection{Company size}

SMEs especially have an important part in using public procurement to drive innovation (Geroski 1990). Company size is the most commonly cited factor for success in receiving public procurement contracts. FreshMinds (2008) found that SMEs are only half as likely to be successful in receiving public contracts as private contracts, leading to a reduced interest among SMEs in submitting tenders. A quantitative study of SMEs in the UK found that company size is proportional to the likelihood of receiving public procurement contracts (Pickernell et al. 2011). Stake (2017) confirms this result for public procurement in Sweden. He investigates the effect of evaluating the most economically advantageous tender (MEAT) in public procurement, which should put innovative SMEs at an advantage. However, the probability for SMEs of winning procurement contracts significantly decreases when MEAT rather than lowest price is used as an evaluative criterion. Karjalainen and Kemppainen (2008) associate the lower engagement of SMEs in public procurement with insufficient resources, especially towards legal expertise and administration. Critical barriers to this involvement include overly prescriptive requirements and qualification criteria, along with increasing requirements for SMEs to supply through a third party (Loader 2015).

Other studies have found that there is a trend toward longer contracts (Procurement Innovation Group 2009), and that contracts that are too large pose a barrier for small companies (Uyarra et al. 2014). Such difficulties facing smaller companies are used to justify the need to increase their competitiveness to support fair competition. Loader (2011) suggests that shorter contracts or subdividing larger contracts would help increase their competitiveness, supported in the procurement directive recommending purchases 'should be adapted to the needs of SMEs' (EC 2014, p. 79). Based on this, it might be expected that company size should have a positive effect on the receipt of public procurement contracts.

\subsection{Export intensity}

With the option of designing tenders to exceed certain sector-specific thresholds, European procurers have the option of opening tenders to competition from abroad. From the perspective of public procurers, it might be on the one hand reasonable to concentrate on domestic companies to stabilize their revenues in the short term. In the long term, particularly, public procurement of innovation has the goal of improving the export potential of companies by raising the requirements (Palmberg 2002). Acting similarly to regulation as per the Porter Hypothesis, tenders that drive innovation force companies to invest in R\&D lead to improved domestic markets for these companies, in addition to improving their efficiency and effectiveness of providing goods and services to public authorities (Putten 2012). These conditions support productivity increases and consequently success 
in exports [see Palmberg (2002) on the success of Nokia and Vecchiato and Roveda (2014) on companies in an Italian region].

The potential to create these company and market impacts depends on tender design: calls for tenders that are too prescriptive or limited to a certain (idiosyncratic national) design can reduce the chances of domestic companies' success in export markets (Edquist and Zabala-Iturriagagoitia 2012). This underscores the potential for standards to be overapplied in tenders due to a lack of ability on behalf of the procuring agency, closing competition to new ideas and more competitors. Beyond numerous potential policy measures, public procurers may face pressure to increase demand-side incentives to innovate based on comparisons between countries (e.g., Rainville 2016; Appelt and Galindo-Rueda 2016). Domestic procurers may not feel pressured to make their purchases more innovative if they perceive a lack of innovation potential in export markets, as suggested for the UK by Georghiou (2007).

\subsection{Sector}

Since the number of public procurement contracts and their volume depend very much on the sector a company is active in, we must control for a companies' sector. For example, both in the construction and information technology (IT) sectors, the public sector has a high demand such as for buildings and regular updates of IT infrastructure. Certain sectors exist primarily for government purchasing, such as manufacture of weapons and spacecraft, and companies operating in sectors in which government activity is concentrated are more likely to benefit from receipt of contracts (Aschhoff and Sofka 2009). However, while there are some sectors in which public procurement is more common, this does not necessarily equate to the size of the demand (Shingal 2015), for contracts may be smaller or of less value. In sectors with greater public demand compared to domestic output, a propensity for the public sector to select domestic firms can reduce trade between countries, particularly if these sectors are characterized by monopolies and returns to scale (Trionfetti 2000). The sector in which a procurement is taking place may also influence the selection criteria used-for instance, for those within the energy sector, cost-effectiveness may extend to life cycle costs to consider potential savings over the longer term (Wegweiser et al. 2009). In Germany, the sectors with the greatest estimated procurement expenditures are property, land leases, and rent (near $20 \%$ of expenditure), and construction (22.4\%). In terms of number of contracts awarded, volume is distributed evenly, with education and research, and transport and communications, each receiving $16 \%$, social security receiving $13 \%$, defense approximately $10 \%$. Less common procurements are for policies and centralized management, security and order, and health and environment (Lorenz et al. 2009).

\subsection{Company strategy}

Public procurement can establish the demand necessary to create new markets for innovation-intensive products (Kok 2004), particularly in areas where there is high investment required and where companies are risk-averse. Involvement in public procurement at the domestic level for German companies opens up access to markets at the federal, state, and local level (BMBF 2006; Lorenz et al. 2009), estimated at 247 billion euros (Wegweiser et al. 2009). As such, the desire to expand markets may predict receipt of public procurement contracts at the domestic level. 
The purpose of calls for tenders in public procurement is to stimulate competition so that the public entity can receive goods or services at sufficient quality at the right price. However, in part due to the common procurement of "off-the-shelf" goods and services, there is often an emphasis on price as the most important criteria in awarding public procurement contracts. Benefits of negotiation techniques in increasing the value available to procurers was found by Erridge and Nondi (1994) for procurers who were advocates of partnership-based rather than competitive procurements, and partially explained by certification according to minimum quality standards.

\subsection{Competitive landscape}

The competitive environment of a company may influence its success in receiving public contracts, depending on the degree to which the design of the call for tender creates different conditions then do private markets. For example, the degree to which a company's products are easily replaced by competitors may influence their success in procurement, such as in the case of common or off-the-shelf products or services (EC 2014, p. 76; Article 63) where other potential suppliers may readily meet the requirements of the procurer. As only $10 \%$ of public procurement contracts in Germany are estimated to be related to innovation (Wegweiser et al. 2009), it is expected that companies engaged in procurement will often compete on prices for interchangeable goods. Current procurement rules have an 'overarching focus on maximizing competition' (Thai 2009, p. 2) that will help secure competitive prices for public purchasers (Rolfstam 2014), generating variety in more open calls and increasing the efficiency of the selection process (Georghiou 2007, p. 11). However, if too much competition is generated then many companies may be disadvantaged. For example, competition on pricing is especially an obstacle to small companies seeking to obtain public procurement contracts (Michaelis et al. 2003).

Companies facing higher threats to their market position through the entry of new competitors may also influence success in public procurement. The entry of new competitors is associated with greater product variety and differentiation possible through public procurement, particularly in markets driven by innovation and competition (Edler et al. 2014). However, risk-averse behaviour of public purchasers taken in efforts to abide by public procurement law may result in a lack of demand for innovation and inflexibility that can hinder competition (Knutsson and Thomasson 2014).

The degree of competition from foreign providers has a potential effect on procurement success. Many of these calls for tenders are closed to suppliers from abroad, with values below set thresholds that would otherwise require disclosure and opening to companies from abroad (EC 2014). Although no aggregated statistics are available, there are approximately ten times more companies in Germany than public procurers, i.e. 300,000 (KutlinaDimitrova and Lakatos 2016) and 35,000 (Staffelt 2004) respectively. Kutlina-Dimitrova and Lakatos (2016) identify around 15,000 tenders from within Germany above the thresholds between 2008 and 2012, requiring European-wide calls. ${ }^{4}$ Germany has the largest proportion of tenders for works below tender value threshold levels across all EU countries, at 95\% of all domestic work contracts (London Economics, ECORYS, \& PWC 2011).

$\overline{4}$ This value is taken from Tenders Electronic Daily (TED), which does not collect domestic calls. 


\section{Empirical analysis}

\subsection{Data}

The data for this analysis is from the Mannheim Innovation Panel's 2013 Innovation Survey, with company-level data on innovation activities of German companies from 2010 to 2012. The survey is conducted annually by the Centre for European Economic Research (ZEW) on behalf of the German Federal Ministry of Education and Research. The methodology and questionnaire are harmonized with the Community Innovation Survey (CIS) conducted at the European level. The 2013 survey included questions regarding the receipt of public procurement contracts between 2010 and 2012, as well as innovation undertaken either directly or in association with any contracts received. The data was matched with data on company engagement in standardization at the German Standardization Office (DIN) over the same period. Due to the very limited number of existing service standards, companies in the service sector are omitted from our analysis, which instead focuses on manufacturing companies. Of the 8740 total responses 3202 companies can be attributed to the manufacturing sector. 1969 companies in the dataset provided valid responses, i.e. they include no missing information for any of the variables selected for inclusion in the analysis. To address concerns that the restricted sample might induce a bias in the variables used in our model, we ran two-sample t-tests on the means of the variables (see Table 3, column 2). We do not find significant differences between our restricted sample and the whole sample of manufacturing firms. Hence, we assume that our sample is still representative for German companies from the manufacturing sector. Germany currently has no method of measuring results of its procurement strategies (OECD 2015). Therefore, a database of more detailed information regarding procurement is not available.

\subsection{Variables}

We conceptualize success in public procurement as the receipt of domestic public procurement contract(s) within the years 2010-2012. Hence, the dependent variable bade takes on the value 1 if the company received any procurement contracts and 0 otherwise.

To test H1, we introduce two variables as alternative proxies of the innovativeness of a company. First, we use the percentage of sales that can be attributes to new or significantly improved products (inno). For a more detailed justification of our conceptualization of innovation success, we refer to Aschhoff and Sofka (2009) and Laursen and Salter (2006). Second, as one robustness check, we additionally introduce the variable prodinno, a binary variable that takes on a value of 1 , if the company introduced a product innovation over the last 3 years and 0 otherwise. However, these conceptualizations of innovation success might suffer from the fact that they solely rely on product innovation. Following the arguments of Rammer et al. (2009), that especially process innovations which can reduce costs will be neglected by using our approach, we introduce their specification of innovation success as a third conceptualization to further expand the robustness of our analysis. Therefore, innosuc represents the number of distinctive types of innovation (market novelties, product line novelties, efficiency innovation, quality innovation) introduced by the company.

Formal standardization organizations exist at the national, European, and international level. However, the engagement at the national level is in general the requirement for 
supranational activities. To test $\mathrm{H} 2$, we introduce a binary variable stand that takes on the value of 1 if the company is engaged in standardization, or more specifically, is involvement at the national SDO DIN. Involvement at DIN is an indicator for firms that both helped to set standards and implemented standards, whereas those which are not engaged are only able to implement standards and thus may have reduced competitiveness due to higher adaption costs.

As discussed above several controls were introduced to the model. For company characteristics, company size (as the log number of employees-variable size) and exports as a share of total sales (exportint) are used. As the number of employees has a very skewed distribution-the log was used instead to control for this skewed distribution. To account for potential non-linear effects in size, the squared term size 2 was included as well. Company strategies of developing new markets outside of Germany (newmarkets), improving the quality of existing products or services (qualimprv), and forming alliances or partnerships with other companies or organizations (partnership) were also introduced. To account for the competitive landscape a company is facing, the degree to which products were readily replaceable by competitors (prodreplace), the extent of the threat of new market entrants to the company's market position (marketthreat), and the degree of competition from foreign providers (foreigncomp) were incorporated. Variables that depict company strategy and competitive landscape are coded from 0 (does not apply) to 3 (strongly agree).

Only companies belonging to the manufacturing sector were included in our analysis. As the number of public procurement contracts available differs according to sector (Aschhoff and Sofka 2009), dummy variables controlling for sector effects are introduced by using twodigit Nace Rev. 2 codes (for a list of sectors within the manufacturing industry see Table 1). The base category for the sector controls was made to be the sectors Nace 10-18, as it represents the largest category with $28.8 \%$ of the companies sampled.

The correlation matrix for all variables used can be found in Table 5. The variance inflation factors (VIF) are reported in Table 2, with a maximum VIF of 1.68 and a mean VIF of 1.27. Combining the VIFs and the correlations indicates that multicollinearity is not a concern with our sample (O'Brien 2007).

\subsection{Methodology}

Our dependent variable that represents if a company received a domestic public procurement contract in the years 2010-2012 constitutes a binary variable. We model the conditional probability of our dependent variable bade with respect to our independent variables $x$ by

$$
\tau_{i} \equiv \operatorname{Prob}\left(\text { bade }_{i}=1 \mid x\right)=F\left(x_{i}^{\prime} \beta\right)
$$

where $x$ is a $(k x 1)$ regressor vector, and $\beta$ is the $(k x 1)$ vector of coefficients to be estimated. We follow Wooldridge (2010) by specifying $F$ as the cumulative distribution function of the logistic distribution. Accordingly, the logit regression model coefficients are estimated using the maximum likelihood estimator. The reported standard errors are robust to heteroskedasticity. Our model specification is formulized as follows:

$$
\begin{aligned}
\operatorname{Prob}_{\left(\text {bade }_{i}=1 \mid x\right)=} & \beta_{0}+\beta_{1} \text { inno }_{i}+\beta_{2} \text { stand }_{i}+\beta_{3} \text { size }_{i}+\beta_{4} \text { size }_{i} \\
& +\beta_{5} \text { exportint }_{i}+\beta_{6} \text { newmarkets }_{i}+\beta_{7} \text { qualimprv }_{i} \\
& +\beta_{8} \text { artnership }_{i}+\beta_{9} \text { prodreplace }_{i}+\beta_{10} \text { marketthreat }_{i} \\
& +\beta_{11} \text { foreigncomp }_{i}+z_{i}^{\prime} \alpha+u_{i}
\end{aligned}
$$


Table 1 Variable abbreviations and descriptions

\begin{tabular}{|c|c|}
\hline Variable abbreviation & Variable description \\
\hline bade & $\begin{array}{l}\text { Receipt of a public procurement contract in } \\
2010-2012 \text { (yes or no) }\end{array}$ \\
\hline \multicolumn{2}{|c|}{ Innovation and standardization-related factors } \\
\hline inno & $\begin{array}{l}\text { Percentage of sales with new or significantly } \\
\text { improved products that were introduced in } \\
2010-2012 \text { (ratio) }\end{array}$ \\
\hline prodinno & $\begin{array}{l}\text { Introduction of product innovations in 2010-2012 } \\
\quad \text { (yes or no) }\end{array}$ \\
\hline innosuc & $\begin{array}{l}\text { Number of distinctive types of innovation (market } \\
\text { novelties, product line novelties, efficiency innova } \\
\text { tion, quality innovation, see Rammer et al. (2009)) }\end{array}$ \\
\hline rdInt & $\begin{array}{l}\text { Internal R\&D expenditure as a share of total sales } \\
\text { (ratio) }\end{array}$ \\
\hline patents & $\begin{array}{l}\text { Assessment of the importance of patents as a way to } \\
\text { ensure and improve competitiveness (yes or no) }\end{array}$ \\
\hline stand & Engagement in standardization activities (yes or no) \\
\hline \multicolumn{2}{|c|}{ Company characteristics, strategy and competitive landscape } \\
\hline size & Company size (log number of employees) \\
\hline exportint & $\begin{array}{l}\text { Export intensity-exports as a share of total sales } \\
\text { (ratio) }\end{array}$ \\
\hline newmarkets & $\begin{array}{l}\text { Development of new markets outside of Germany } \\
(0-3)\end{array}$ \\
\hline qualimprv & $\begin{array}{l}\text { Improve the quality of existing products or services } \\
(0-3)\end{array}$ \\
\hline partnership & $\begin{array}{l}\text { Formation of alliances or partnerships with other } \\
\text { companies/organizations }(0-3)\end{array}$ \\
\hline prodreplace & Products are easy to replace by competitors $(0-3)$ \\
\hline marketthreat & $\begin{array}{l}\text { High threat to market position through the entry of } \\
\text { new competitors }(0-3)\end{array}$ \\
\hline foreigncomp & Strong competition from foreign providers $(0-3)$ \\
\hline
\end{tabular}

Economic sector within the manufacturing industry based on NACE Rev. 2

edbls, textiles, wood

chemicals

pharmaceutical

rubber, plastic, metal

fabr. metal

comp., elec., optic.

elec., mach., vehic.
Nace 10-18 Manufacture of food products, beverages, tobacco products, textiles, wearing apparel, leather and related products, wood and of products of wood, paper and paper products, printing and reproduction of recorded media (yes or no)

Nace 20-Chemicals and chemical products (yes or no)

Nace 21-Basic pharmaceutical products and pharmaceutical preparations (yes or no)

Nace 22-24-Rubber and plastic products, other non-metallic mineral products. Basic metals (yes or no)

Nace 25-Fabricated metal products. Except machinery and equipment (yes or no)

Nace 26-Computer, electronic and optical products (yes or no)

Nace 27-29-Electrical equipment, machinery and equipment n.e.c., motor vehicles, trailers and semitrailers (yes or no) 
Table 1 (continued)

\begin{tabular}{ll}
\hline Variable abbreviation & Variable description \\
\hline wtr., rail., spce trnsp. & $\begin{array}{l}\text { Nace } 30-\text { Building of ships and boats; Manufacture } \\
\text { of railway locomotives and rolling stock; Air and } \\
\text { spacecraft and related machinery; Other transport } \\
\text { equipment (yes or no) }\end{array}$ \\
Nace 31-Furniture (yes or no) \\
furniture & $\begin{array}{l}\text { Nace 32-Other manufacturing excluding medical } \\
\text { other manuf., medical, dental }\end{array}$ \\
& $\begin{array}{l}\text { and dental instruments and supplies; Medical and } \\
\text { dental instruments and supplies (yes or no) }\end{array}$ \\
mach. repair, instlln. & Nace 33-Repair and installation of machinery and \\
& equipment (yes or no) \\
\hline
\end{tabular}

Table 2 Descriptive statistics and variance inflation factors (VIF)

\begin{tabular}{|c|c|c|c|c|c|c|}
\hline Variable & $\mathrm{N}$ & Mean & Std. Dev. & Min & Max & VIF \\
\hline bade & 1969 & 0.155409 & 0.362386 & 0 & 1 & - \\
\hline inno & 1969 & 1.185445 & 1.517151 & 0 & 4.61512 & 1.55 \\
\hline prodinno & 1969 & 0.390554 & 0.487998 & 0 & 1 & - \\
\hline innosuc & 1969 & 0.820213 & 1.153898 & 0 & 4 & - \\
\hline stand & 1969 & 0.071102 & 0.257061 & 0 & 1 & 1.18 \\
\hline rdInt & 1969 & 0.026256 & 0.283271 & 0 & 10.38961 & 1.68 \\
\hline patents & 1969 & 0.381412 & 0.485857 & 0 & 1 & 1.03 \\
\hline size & 1969 & 3.720749 & 1.513328 & 0 & 10.61209 & 1.5 \\
\hline size2 & 1969 & 16.13297 & 13.20166 & 0 & 112.6165 & - \\
\hline exportint & 1969 & 0.200847 & 0.322026 & 0 & 9.109735 & 1.39 \\
\hline newmarkets & 1969 & 1.268156 & 1.071483 & 0 & 3 & 1.8 \\
\hline qualimprv & 1969 & 2.418994 & 0.81317 & 0 & 3 & 1.1 \\
\hline partnership & 1969 & 0.898426 & 0.917226 & 0 & 3 & 1.15 \\
\hline prodreplace & 1969 & 1.74454 & 0.921873 & 0 & 3 & 1.29 \\
\hline marketthreat & 1969 & 1.49873 & 0.814704 & 0 & 3 & 1.29 \\
\hline foreigncomp & 1969 & 1.486541 & 0.992321 & 0 & 3 & 1.28 \\
\hline edbls, textiles, wood & 1969 & 0.288979 & 0.453403 & 0 & 1 & - \\
\hline ref. petrol, coke & 1969 & 0.006602 & 0.081007 & 0 & 1 & 1.03 \\
\hline chemicals & 1969 & 0.051295 & 0.220655 & 0 & 1 & 1.17 \\
\hline pharmaceutical & 1969 & 0.01676 & 0.128403 & 0 & 1 & 1.07 \\
\hline rubber, plastic, metal & 1969 & 0.155917 & 0.362869 & 0 & 1 & 1.37 \\
\hline fabr. metal & 1969 & 0.116811 & 0.321276 & 0 & 1 & 1.29 \\
\hline comp., elec., optic. & 1969 & 0.077704 & 0.267774 & 0 & 1 & 1.31 \\
\hline elec., mach., vehic. & 1969 & 0.187405 & 0.390335 & 0 & 1 & 1.51 \\
\hline wtr., rail., spce trnsp. & 1969 & 0.020315 & 0.141111 & 0 & 1 & 1.07 \\
\hline furniture & 1969 & 0.029964 & 0.170533 & 0 & 1 & 1.08 \\
\hline other manuf., Medical, dental & 1969 & 0.037075 & 0.188993 & 0 & 1 & 1.1 \\
\hline mach. repair, instlln. & 1969 & 0.011173 & 0.105138 & 0 & 1 & 1.03 \\
\hline
\end{tabular}


where the vector $z$ contains the sector dummies and $\alpha$ the respective coefficients to be estimated.

To account for potential endogeneity problems with respect to our dependent variable of main interest (inno), we include two instrumental variables in our model. For instrumental variables to be appropriate they need to be correlated with the potentially endogenous regressor in question (inno) and uncorrelated with the error term of the regression model to be estimated (Wooldridge 2010): First, internal R\&D intensity measured as internal R\&D expenditure over total turnover $(r d I n t)$, which was selected rather than external intensity to coincide with activities within the company. Second, the assessment of the importance of patents to ensure and improve competitiveness in the market (patents). The variable patents is measured as a binary variable that takes on the value 1 , if the rates the importance of patents as at least low. It seems to be widely accepted that R\&D is positively linked to the innovation performance of companies (Artz et al. 2010; Griliches 1986; Hall and Bagchi-Sen 2002). Further, there is strong evidence that a positive link between patent strategies and innovation performance exists (Bloom and van Reenen 2002), because patents provide exclusive rights to develop new innovations, but also reduce the effect of market uncertainty on the firm's investment decision (Czarnitzki and Toole 2011). In addition, a valid instrument should not exert a direct effect on the probability to receive a public procurement contract. We argue this to be true, as both variables are not observed by the public procurers, nor do they play a role in the allocation process of procurement contracts. Hence, our instruments only affect the probability of receiving procurement contracts through their indirect effects on the innovation performance of the companies.

\section{Results and discussion}

\subsection{Descriptive statistics}

Table 2 contains the descriptive statistics and variance inflation factors for all variables used in the various model specifications. Overall, about $16 \%$ of companies in the sample received domestic public procurement contracts. Companies generated about $10 \%$ of their sales with new or significantly improved products and almost $40 \%$ of the sampled companies introduced product innovations within the last 3 years. About $7.1 \%$ of the companies in the sample are actively participating in standardization processes on the national level. On average, $2.6 \%$ of sales are spend on internal R\&D projects while $38 \%$ of the companies in the sample attribute at least some importance to patents as a way to ensure and improve their competitiveness in the market. Companies in our sample have on average about 216 employees.

Table 3 contains the means and significance levels for two-sample t-tests for all variables separated for firms that received public procurements contracts and those that did not (column 1). Column 2 shows the means and the according significance levels for firms that were in the original sample compared to the final sample used for our analyses. Companies that received public procurement contracts have a significantly higher propensity to introduce product innovations. The average number of companies undertaking product innovation, particularly, is significantly greater at $52.3 \%$ compared to $36.6 \%$. Further, companies that receive public procurement contracts generate a higher percentage of their sales by selling new or significantly improved products and introduce a higher number of distinctive types of innovations (market novelties, product line novelties, efficiency innovation, 
Table 3 Means and results of the two-sample t-Tests for all variables used in the models

\begin{tabular}{lll}
\hline Variable & $\begin{array}{l}\text { Means of companies with domestic } \\
\text { contracts } \\
\text { yes (no) }\end{array}$ & $\begin{array}{l}\text { Means of companies } \\
\text { in the original sample } \\
\text { yes (no) }\end{array}$ \\
\hline bade & $-(-)$ & $0.151(0.155)$ \\
inno & $1.114(1.572)^{* * *}$ & $1.209(1.185)$ \\
prodinno & $0.366(0.523)^{* * *}$ & $0.39(0.391)$ \\
innosuc & $0.778(1.049)^{* * *}$ & $0.785(0.82)$ \\
stand & $0.064(0.108)^{* * *}$ & $0.073(0.071)$ \\
rdInt & $0.026(0.03)$ & $0.023(0.026)$ \\
patents & $0.37(0.441)^{* *}$ & $0.37(0.381)$ \\
size & $3.736(3.639)$ & $3.672(3.721)$ \\
size2 & $16.196(15.792)$ & $15.879(16.133)$ \\
exportint & $0.201(0.198)$ & $0.201(0.201)$ \\
newmarkets & $1.273(1.24)$ & $1.223(1.268)$ \\
qualimprv & $2.413(2.454)$ & $2.408(2.419)$ \\
partnership & $0.877(1.013)^{* *}$ & $0.874(0.898)$ \\
prodreplace & $1.744(1.748)$ & $1.708(1.745)$ \\
marketthreat & $1.515(1.408)^{* *}$ & $1.49(1.499)$ \\
foreigncomp & $1.499(1.418)$ & $1.457(1.487)$ \\
edbls, textiles, wood & $0.304(0.209)^{* * *}$ & $0.297(0.289)$ \\
ref. petrol, coke & $0.007(0.007)$ & $0.008(0.007)$ \\
chemicals & $0.056(0.026)^{* *}$ & $0.052(0.051)$ \\
pharmaceutical & $0.019(0.007)$ & $0.017(0.017)$ \\
rubber, plastic, metal & $0.158(0.147)$ & $0.147(0.156)$ \\
fabr. metal & $0.116(0.121)$ & $0.109(0.117)$ \\
comp., elec., optic. & $0.067(0.134)^{* * *}$ & $0.078(0.078)$ \\
elec., mach., vehic. & $0.188(0.186)$ & $0.181(0.187)$ \\
wtr., rail., spce trnsp. & $0.016(0.042)^{* * *}$ & $0.025(0.02)$ \\
furniture & $0.024(0.062)^{* * *}$ & $0.031(0.03)$ \\
other manuf., Medical, dental & $0.035(0.046)$ & $0.04(0.037)$ \\
mach. repair, instlln. & $0.011(0.013)$ & $0.014(0.011)$ \\
\hline & & \\
& &
\end{tabular}

$* * * p<0.01 ; * * p<0.05 ; * p<0.1$

quality innovation). They are also slightly more likely to rate high on the importance of patents. Engagement in standardization is almost twice as common in firms who receive procurement contracts, at $10.8 \%$ compared to $6.4 \%$ for the whole sample of manufacturing companies.

The majority of all companies engaged in procurement were SMEs, comprising $87.76 \%$ of the sample. ${ }^{5}$ We do not find significant differences in size between companies

\footnotetext{
5 SMEs were defined according to limitations on employee numbers and turnover size as the EU definitions in OECD (2005) OECD SME and Entrepreneurship Outlook: 2005, OECD Paris, page 17 from http://stats .oecd.org/glossary/detail.asp?ID=3123.
} 
that receive public procurement and those that do not. These findings directly contradict the concerns referenced in the literature citing the disadvantage of SMEs in public procurement, where larger companies are often seen as being more likely to receive contracts (e.g. by Stake 2017). Companies receiving contracts face less market competition and are more active in forming alliances. Further, it is evident that there exists a great variation of the likelihood to receive procurement contracts between the various sectors. While for some sectors companies that received public procurement contracts are overrepresented (e.g. Nace 20-Chemicals and chemical products), they are significantly underrepresented for others (e.g. Nace 26-Computer, electronic and optical products). This result indicates that including sector dummies as control variables to our regression analyses can be considered a very important step to account for sector specific differences in procurement success.

\subsection{Regression results}

Table 4, column 1 depicts the results of the binary logistic regression. The results support $\mathrm{H} 1$, in that more innovative companies are significantly more likely to receive domestic procurement contracts. Hence, our findings are in line with those in the case of the UK by Georghiou et al. (2014), where more than half of firms won a public contract due to innovation of some sort, and Uyarra et al. (2014) who reported that less innovative companies face particular barriers to procurement.

Our results further lend support to $\mathrm{H} 2$, in that company engagement in standardization significantly predicts the receipt of domestic procurement contracts by German companies. While standardization activity at the European or international level is not available in a database, approximately half of German companies who are involved in national standardization are active at these higher levels (Blind et al. 2014). Additionally, firms are highly unlikely to meet public procurers in standardization at international levels, despite their presence at national discussions. The involvement in standardization seems to provide companies with knowledge relevant for the success in public procurement including contacts to public procurers involved in standardization and possible partners for common procurement activities. This explanation is also supported by the positive effect of the strategy to form external alliances or partnerships on the likelihood of receiving domestic public procurement contracts.

Regarding the company's competitive landscape, most variables are influential for domestic procurement contracts. Our findings suggest that those who receive domestic contracts are more likely to operate in an environment with relatively low competition. Companies producing products more replaceable by competitors are more likely to be successful in procurement, which may be influenced by the existence of a greater number of calls for tenders for the provision of relatively commonplace goods by those companies in the manufacturing industry, as compared to more innovative procurement. In Germany, multiple federal ministries collaborate toward greater consideration of innovative solutions in public procurement, which contributes to over 10\% of Germany's GDP in 2006 (Wegweiser et al. 2009). Lower threats to market position also significantly impact the receipt of public procurement contracts, which may limit the openness and competition stimulated by public procurement, as well as the market and innovation benefits that procurement can leverage.

Company strategies also significantly influence company success in domestic public procurement. Companies which receive domestic contracts are less likely to seek the 
Table 4 Estimations results to explain success in domestic public procurement

\begin{tabular}{|c|c|c|c|c|c|c|}
\hline $\begin{array}{l}\text { Dependent vari- } \\
\text { able: Success in } \\
\text { public procure- } \\
\text { ment }\end{array}$ & (1) & (2) & (3) & (4) & (5) & (6) \\
\hline Variables & LOGIT & IVPROBIT & 2SLS & LIML & GMM & LEWBEL \\
\hline inno & $\begin{array}{l}0.224 * * * \\
(0.0430)\end{array}$ & $\begin{array}{l}0.161 * * \\
(0.0665)\end{array}$ & $\begin{array}{l}0.0322 * * \\
(0.0152)\end{array}$ & $\begin{array}{l}0.0322 * * \\
(0.0152)\end{array}$ & $\begin{array}{l}0.0319 * * \\
(0.0152)\end{array}$ & $\begin{array}{l}0.0412 * * \\
(0.0168)\end{array}$ \\
\hline stand & $\begin{array}{l}0.619 * * * \\
(0.239)\end{array}$ & $\begin{array}{l}0.355^{* *} \\
(0.138)\end{array}$ & $\begin{array}{l}0.0843 * * \\
(0.0378)\end{array}$ & $\begin{array}{l}0.0843 * * \\
(0.0378)\end{array}$ & $\begin{array}{l}0.0845^{* *} \\
(0.0378)\end{array}$ & $\begin{array}{l}0.0831 * * \\
(0.0378)\end{array}$ \\
\hline size & $\begin{array}{l}-0.316^{* * *} \\
(0.160)\end{array}$ & $\begin{array}{l}-0.182 * * \\
(0.0921)\end{array}$ & $\begin{array}{l}-0.0395^{*} \\
(0.0228)\end{array}$ & $\begin{array}{l}-0.0395^{*} \\
(0.0228)\end{array}$ & $\begin{array}{l}-0.0401^{*} \\
(0.0228)\end{array}$ & $\begin{array}{l}-0.0382^{*} \\
(0.0228)\end{array}$ \\
\hline size2 & $\begin{array}{l}0.0263 \\
(0.0178)\end{array}$ & $\begin{array}{l}0.0146 \\
(0.0104)\end{array}$ & $\begin{array}{l}0.00329 \\
(0.00261)\end{array}$ & $\begin{array}{l}0.00329 \\
(0.00261)\end{array}$ & $\begin{array}{l}0.00335 \\
(0.00261)\end{array}$ & $\begin{array}{l}0.00309 \\
(0.00261)\end{array}$ \\
\hline exportint & $\begin{array}{l}-0.0257 \\
(0.169)\end{array}$ & $\begin{array}{l}-0.0299 \\
(0.101)\end{array}$ & $\begin{array}{l}-0.00374 \\
(0.0206)\end{array}$ & $\begin{array}{l}-0.00374 \\
(0.0206)\end{array}$ & $\begin{array}{l}-0.00332 \\
(0.0206)\end{array}$ & $\begin{array}{l}-0.00674 \\
(0.0203)\end{array}$ \\
\hline newmarkets & $\begin{array}{l}-0.175^{* *} \\
(0.0788)\end{array}$ & $\begin{array}{l}-0.112^{* *} \\
(0.0507)\end{array}$ & $\begin{array}{l}-0.0222^{* *} \\
(0.0110)\end{array}$ & $\begin{array}{l}-0.0222 * * \\
(0.0110)\end{array}$ & $\begin{array}{l}-0.0220^{* *} \\
(0.0110)\end{array}$ & $\begin{array}{l}-0.0261^{* *} \\
(0.0108)\end{array}$ \\
\hline qualimprv & $\begin{array}{l}0.0378 \\
(0.0827)\end{array}$ & $\begin{array}{l}0.0202 \\
(0.0464)\end{array}$ & $\begin{array}{l}0.00460 \\
(0.0101)\end{array}$ & $\begin{array}{l}0.00460 \\
(0.0101)\end{array}$ & $\begin{array}{l}0.00457 \\
(0.0101)\end{array}$ & $\begin{array}{l}0.00328 \\
(0.00978)\end{array}$ \\
\hline partnership & $\begin{array}{l}0.127 * \\
(0.0710)\end{array}$ & $\begin{array}{l}0.0661 \\
(0.0413)\end{array}$ & $\begin{array}{l}0.0149 \\
(0.00971)\end{array}$ & $\begin{array}{l}0.0149 \\
(0.00971)\end{array}$ & $\begin{array}{l}0.0150 \\
(0.00971)\end{array}$ & $\begin{array}{l}0.0131 \\
(0.00971)\end{array}$ \\
\hline prodreplace & $\begin{array}{l}0.204 * * \\
(0.0818)\end{array}$ & $\begin{array}{l}0.114 * * \\
(0.0445)\end{array}$ & $\begin{array}{l}0.0242 * * \\
(0.00995)\end{array}$ & $\begin{array}{l}0.0242 * * \\
(0.00995)\end{array}$ & $\begin{array}{l}0.0243 * * \\
(0.00995)\end{array}$ & $\begin{array}{l}0.0248 * * \\
(0.00997)\end{array}$ \\
\hline marketthreat & $\begin{array}{l}-0.244 * * * \\
(0.0907)\end{array}$ & $\begin{array}{l}-0.135^{* * *} \\
(0.0494)\end{array}$ & $\begin{array}{l}-0.0287 * * * \\
(0.0108)\end{array}$ & $\begin{array}{l}-0.0287 * * * \\
(0.0108)\end{array}$ & $\begin{array}{l}-0.0287 * * * \\
(0.0108)\end{array}$ & $\begin{array}{l}-0.0293 * * * \\
(0.0109)\end{array}$ \\
\hline foreigncomp & $\begin{array}{l}-0.0703 \\
(0.0702)\end{array}$ & $\begin{array}{l}-0.0391 \\
(0.0390)\end{array}$ & $\begin{array}{l}-0.00924 \\
(0.00850)\end{array}$ & $\begin{array}{l}-0.00924 \\
(0.00850)\end{array}$ & $\begin{array}{l}-0.00914 \\
(0.00850)\end{array}$ & $\begin{array}{l}-0.00854 \\
(0.00855)\end{array}$ \\
\hline Constant & $\begin{array}{l}-1.576^{* * * *} \\
(0.389)\end{array}$ & $\begin{array}{l}-0.929 * * * \\
(0.218)\end{array}$ & $\begin{array}{l}0.181 * * * \\
(0.0521)\end{array}$ & $\begin{array}{l}0.181 * * * \\
(0.0521)\end{array}$ & $\begin{array}{l}0.182 * * * \\
(0.0521)\end{array}$ & $\begin{array}{l}0.179 * * * \\
(0.0524)\end{array}$ \\
\hline Sector dummies & Yes & Yes & Yes & Yes & Yes & Yes \\
\hline IV & No & Yes & Yes & Yes & Yes & Yes \\
\hline Observations & 1969 & 1969 & 1969 & 1969 & 1969 & 1969 \\
\hline R-squared & & & 0.052 & 0.052 & 0.052 & 0.050 \\
\hline Pseudo R2 & 0.0581 & & & & & \\
\hline log likelihood & -801.1 & -3979 & -742.6 & -742.6 & -742.6 & -744.4 \\
\hline Wald Chi2 & 105.6 & 89.95 & & & & \\
\hline Wald df & 22 & 22 & & & & \\
\hline Wald $p$ value & $<0.0001$ & $<0.0001$ & & & & \\
\hline Hansens J & & & 0.192 & 0.192 & 0.192 & 12.41 \\
\hline$p$ value & & & 0.661 & 0.661 & 0.661 & 0.901 \\
\hline KP rk LM & & & 203.2 & 203.2 & 203.2 & 89.79 \\
\hline$p$ value & & & $<0.0001$ & $<0.0001$ & $<0.0001$ & $<0.0001$ \\
\hline KP rk Wald F & & & 135.4 & 135.4 & 135.4 & 5.299 \\
\hline
\end{tabular}

Coefficients with standard errors in parentheses. All standard errors are robust to heteroskedasticity

The variable measuring innovativeness (inno) in models (2)-(6) are instrumented with the R\&D intensity (rdInt) and the patenting behavior (patents) of the respective company. Respective first-stage results are available from the authors upon request. All models contain dummy variables controlling for 12 different sectors using two-digit Nace rev. 2 codes

$* * * p<0.01 ; * * p<0.05 ; * p<0.1$ 
development of new markets outside of Germany (in Europe, or abroad). This remains somewhat counterintuitive, as procurement is expected to be able to open new markets or offer greater market foothold for companies. It may be the case that companies which focus on public procurement at the domestic level are more likely to be interested in entering new markets in Germany hindering a parallel strategy towards new markets outside of Germany. Improving the quality of existing products as a company strategy does not predict success in domestic procurement. Although as public procurement (and particularly public procurement of innovation) is said to be important to driving market improvements, along with stimulating competition, this finding supports that cost is a primary consideration in public procurement. The test whether the relationship between contract receipt and quality follows is an inverted-U shape did not reveal significant results.

These findings coincide with the greater likelihood of having replaceable products by competitors as influential on the receipt of public procurement contracts, which support previous findings that $90 \%$ of contracts in Germany are for non-innovative products or services (Wegweiser et al. 2009). In addition, companies facing lower threats from new market entrants are more likely to receive contracts.

Although the descriptive findings suggested that there is no significant difference in size between companies that receive public procurement and those that do not, we find that controlling for the remaining factors size is significantly negatively associated with public procurement success. These findings contradict earlier findings in the literature, where larger companies are often said to be at an advantage in the competition on public procurement contracts. On the contrary, we find that smaller companies are more likely to win public procurement contracts. There is no evidence for a u-shape effect in size. Export intensity on the other hand has no significant effect on the likelihood of receiving procurements.

\subsection{Robustness checks}

First, to address potential endogeneity issues, the instrumental variables rdInt and patents were introduced to our model. To estimate our model and to be able to account for the continuous endogenous regressor in our binary choice model, we apply the instrumental variable probit technique based on the minimum Chi squared estimator available in the ivprobit command within Stata 15. We additionally estimate the linear probability model using two-stage least squares (2SLS), the limited-information maximum likelihood (LIML) estimator and the two-step efficient generalized method of moments (GMM) estimator. The results of the different instrumental variable estimation approaches can be found in columns (2) to (5) of Table 4. The results remain strikingly robust, indicating that our results are robust to endogeneity and various model assumptions. Only the variable partnership is no longer significant in the alternative specifications. To test the validity of our instruments Hansen's $\mathbf{J}$ statistic is calculated for all specifications as this statistic is does not demand to commit to the assumption of homoskedasticity. The test statistics and reported $\chi^{2} p$ values of all specifications strongly indicate that we cannot reject the null hypothesis that our instruments are uncorrelated with the error term. Hence, we do not doubt the validity of the chosen instruments. To test the relevance of our instruments, the Kleibergen-Paap rk LM statistic is calculated as it accounts for potential heteroskedasticity. The reported $\chi^{2} p$ values for all specifications are lower than 0.0001 and thus, lends strong support to reject the null hypothesis that that the instrumental variables are not correlated to the endogenous 
regressor. Hence, the equations are identified. Notwithstanding, weak instruments potentially lead to poorly performance of estimators (Stock et al. 2005). Therefore, we additionally carry out weak identification tests to test for weak instruments. The Kleibergen-Paap rk Wald F statistics, which is robust to heteroskedasticity strongly rejects the null hypothesis of weak identification for all specifications. Hence, all tests confirm our trust in the chosen instruments and validate our estimation results.

Second, we use two alternative specifications of the independent variable for the innovativeness of the company. Prodinno is a binary variable that takes on the value of one if the company has introduced a product innovation in the last 3 years. As in this case the endogenous variable is a dichotomous variable as well, using ivprobit would result in biased estimates. Hence, we use the maximum-likelihood seemingly unrelated bivariate probit estimator instead (Heckman 1978). Again, we additionally estimate our model using the 2SLS, LIML and GMM estimators. The results of the different instrumental variable estimation approaches can be found in columns (2) to (5) of Table 6.

Third, innosuc represents the number of distinctive types of innovation (market novelties, product line novelties, efficiency innovation, quality innovation) and was adopted from Rammer et al. (2009). The results of the different instrumental variable estimation approaches (2SLS, LIML, GMM) can be found in columns (2) to (4) of Table 7.

As above we inspected the Hansen J, Kleibergen-Paap rk LM and Kleibergen-Paap rk Wald F statistics. They do not cast doubt on the reliability of our instrumental variables. Therefore, the results shown in Tables 6 and 7 lend further support to our findings.

Fourth, we applied an instrumental variable estimation approach that relies on heteroskedasticity-based instruments introduced by Lewbel (2012). This approach can be applied, when there are no external instruments readily available. Although, we are confident about our instruments, we introduce this method as a further robustness check. Fortunately, the procedure is readily available in the ivreg $2 h$ command by Baum and Schaffer (2012). The Hansen J, Kleibergen-Paap rk LM and Kleibergen-Paap rk Wald F statistics do not raise any concerns with respect to the instrumental variables. The results can be found in the last column of Tables 4, 6 and 7 for all specifications of the innovation variables. Our findings remain robust.

Fifth, we apply a matching estimation procedure to check the robustness of our results to a potential selection problem. The outcome variable is again the receipt of a domestic procurement contract. The treatment variables will be the introduction of product innovations ( $p d p p)$ and the engagement in standardization activities (stand), respectively. For all firms that introduced product innovation or participated in standardization, the approach selects firms that did not do so but are comparable in their observable characteristics. Hence, the remaining difference in their probability to receive the public procurement contract can by attributed to the respective treatment variable (Caliendo and Kopeinig 2008). Common support for the companies is given for all observations in our sample. To achieve the propensity score matching, we relied on propensity score matching with Kernel matching using the Epanechnikov Kernel. The method is readily available in the psmatch2 package in Stata (Leuven and Sianesi 2003). The results can be found in Table 8. For all control variables the $t$ test of the mean between the treatment and control groups are insignificant, meaning that the firms in the control and treatment groups do not differ in their observable characteristics. Nevertheless, both innovativeness and participation in standardization have a significant and positive impact on the likelihood of success in domestic procurement, which again shows the robustness of our results. 


\section{Conclusions and limitations}

There is a significant potential to improve the benefits from public procurement through a better understanding of drivers in company success at the micro-level. This paper serves as an empirical investigation into the effects of innovation activities and standardization on the receipt of public procurement contracts by German companies in the manufacturing industry. It contributes to the knowledge on factors that bring companies to compete successfully for public procurement at the micro-level, an area that has received little study to date, rather than about the impacts of procurement on companies and markets.

Our findings confirm that in fact more innovative companies are more likely to receive public procurement contracts in Germany and therefore are in line with previous findings (Georghiou et al. 2014; Uyarra et al. 2014). Furthermore, company engagement in standardization is associated with a higher likelihood of successful public procurement competitions. This finding is further supported by a positive association between the formation of external alliances and the success in public procurement. With respect to the market environment, we find that relatively low competition and lower market threats are positively linked to procurement success. With respect to company strategies, our findings indicate that companies that are less interested in the development of markets outside of Germany are more likely to receive public procurement contracts. Companies with products that are more replaceable, representing more non-innovative products, are more likely receive public procurement contracts. This is a finding in line with previous research showing that most contracts in Germany are for non-innovative products (Wegweiser et al. 2009). Finally, size is significantly negatively associated with public procurement success.

Our findings have both company-level and policy implications. For companies, they support that engagement in strategic alliances, including standardization activities, as well as undertaking product innovation are associated with an increase in the likelihood of receiving domestic public procurement contracts. Therefore, companies' engagement in standardization activities at standards development organizations may present an opportunity to gain a competitive advantage over the competition in submitting tenders. This might be, since engagement in standardization is providing companies with access to knowledge as well as contacts to public procurers and possible partners for common procurement activities. The ability for a company to meet requirements in tenders that are specified via standards could positively influence their competitiveness toward winning a given public contract. This finding is further substantiated by our finding that the alliances or partnerships increase the likelihood of receiving public procurement contracts. For both companies and policy makers, the finding that smaller firms are more likely to receive public procurement contract is of high importance. First, this finding might provide needed support for smaller companies in their strategic decision to engage in calls for tenders. Second, policy makers might review their public procurement policies in the light of this finding. For policy-makers, our study supports the notion that public procurement is indeed open for companies active in innovation, which is certainly a beneficial condition for public procurement driving innovation policy. Consequently, even more comprehensive policy approaches are needed to particularly address innovation as input dimension into public procurement in general.

Some limitations to this analysis should be noted. First, and possibly most significantly, there is a potential for endogeneity as it may be true that the receipt of public procurement 
contracts within the period of analysis had an impact on companies rather than the reverse. We carefully address this issue by introducing instrumental variables to our estimation approach, which leaves our results qualitatively unchanged. Nevertheless, our results are based on cross-sectional data and therefore we can not claim to make causal inferences. Additional uncertainty is introduced as we do not know the success rate of companies submitting calls for tenders - companies could only answer if they did, or did not, receive public procurement contracts. It may be the case that companies were not successful in receiving contracts over the observed time period although they had submitted calls for tenders.

Additional limitations have to do with procurement characteristics. We are not able to control for different types of tendering in terms of the procurement processes or stages (i.e., collaborative, multi-stage, etc.) or the product being procured, including the extent to which the purchase was intended to stimulate innovation either directly or indirectly (Rolfstam 2014). However, it may be safely assumed that companies would supply goods and services to public organizations in the sector in which they operate. Subsequently, it is assumed that the limitation of the sample to the manufacturing sector also limits the public procurement contracts received to solely those for products that companies in the manufacturing sector can supply. Finally, certain limitations exist for using the CIS dataset. For instance, as the survey is self-reported, responses represent a subjective assessment from the perspective of individual companies. However, the CIS data is representative and has been used for analyses published in highly reputed journals. Furthermore, it is the only dataset that provides insight into the engagement in public procurement of German companies.

A final limitation is the lack of connection to procurement projects. Companies who win contracts are those who have submitted tenders which best fulfil a given set of public specifications and criteria. In this analysis, we cannot determine the extent to which benefits from standardization activities played a role in individual cases, such as whether certain standards a company participated in creating, were introduced into the call for tenders. Further, innovative companies may also be those who have more resources to devote to writing successful tenders. We include size as a variable that controls for the latter, as typically larger companies would also have resources for departments devoted to tender writing activities. If size was an issue, small innovative companies would not likely have the resources to win the best bids; however, we find that innovation is a predictor of success with procurement contracts, regardless of size. Furthermore, we applied an instrumental variable approach to tackle the issue related to the endogeneity of the innovativeness of the companies.

Acknowledgements The authors gratefully acknowledge the valuable suggestions of three anonymous reviewers. Anne Rainville would like to acknowledge the funding and support from Climate-KIC in carrying out this research. Climate-KIC is supported by the European Institute of Innovation and Technology (EIT), a body of the European Union.

Open Access This article is distributed under the terms of the Creative Commons Attribution 4.0 International License (http://creativecommons.org/licenses/by/4.0/), which permits unrestricted use, distribution, and reproduction in any medium, provided you give appropriate credit to the original author(s) and the source, provide a link to the Creative Commons license, and indicate if changes were made.

\section{Appendix}

See Tables 5, 6, 7 and 8 . 


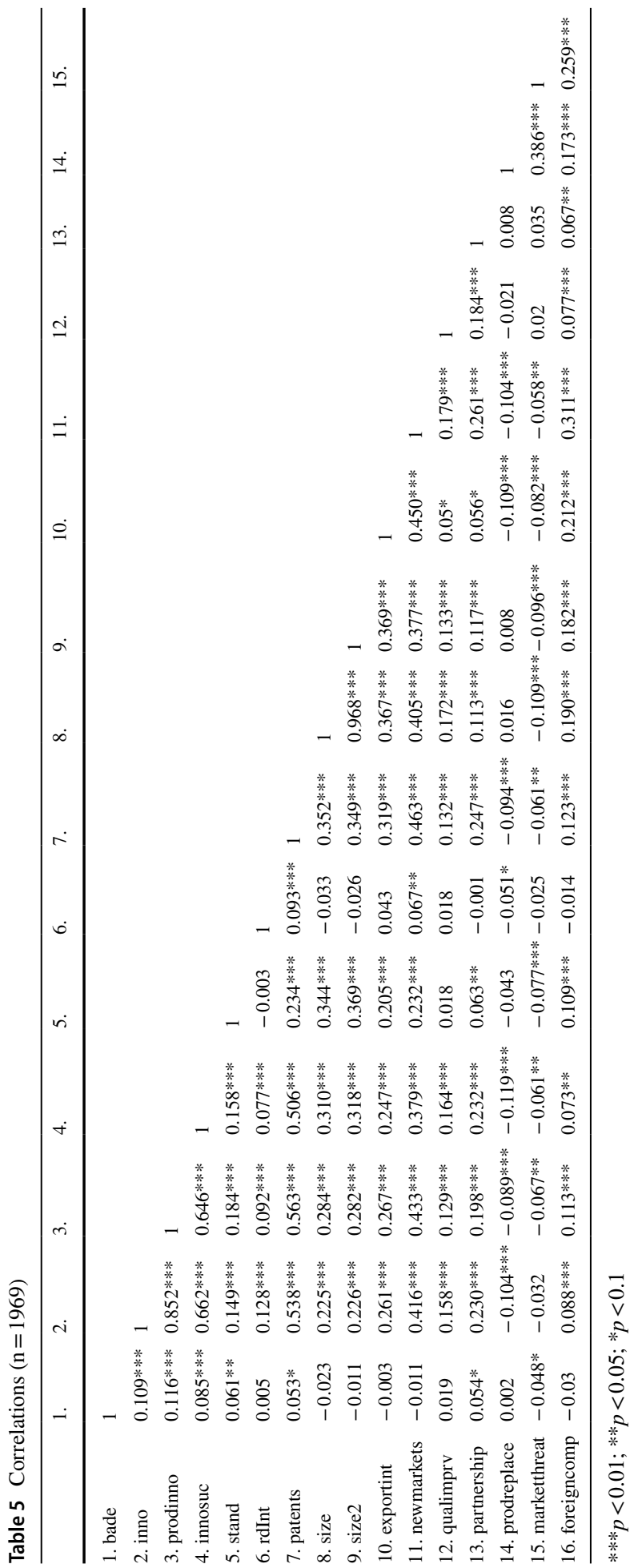


Table 6 Estimations results to explain success in domestic public procurement. Alternative specification of innovation: prodinno

\begin{tabular}{|c|c|c|c|c|c|c|}
\hline $\begin{array}{l}\text { Dependent variable: } \\
\text { Success in public } \\
\text { procurement }\end{array}$ & (1) & (2) & (3) & (4) & (5) & (6) \\
\hline Variables & LOGIT & BIPROBIT & 2SLS & LIML & GMM & LEWBEL \\
\hline prodinno & $\begin{array}{l}0.860 * * * \\
(0.140)\end{array}$ & $\begin{array}{l}0.550 * * \\
(0.233)\end{array}$ & $\begin{array}{l}0.0978 * * \\
(0.0455)\end{array}$ & $\begin{array}{l}0.0978^{* *} \\
(0.0455)\end{array}$ & $\begin{array}{l}0.0974 * * \\
(0.0454)\end{array}$ & $\begin{array}{l}0.252 * * * \\
(0.0602)\end{array}$ \\
\hline stand & $\begin{array}{l}0.584 * * \\
(0.242)\end{array}$ & $\begin{array}{l}0.343^{* * *} \\
(0.140)\end{array}$ & $\begin{array}{l}0.0806^{* *} \\
(0.0381)\end{array}$ & $\begin{array}{l}0.0806 * * \\
(0.0381)\end{array}$ & $\begin{array}{l}0.0806 * * \\
(0.0381)\end{array}$ & $\begin{array}{l}0.0676^{*} \\
(0.0392)\end{array}$ \\
\hline size & $\begin{array}{l}-0.350^{* *} \\
(0.162)\end{array}$ & $\begin{array}{l}-0.199^{* *} \\
(0.0926)\end{array}$ & $\begin{array}{l}-0.0429^{*} \\
(0.0228)\end{array}$ & $\begin{array}{l}-0.0429^{*} \\
(0.0228)\end{array}$ & $\begin{array}{l}-0.0431 * \\
(0.0228)\end{array}$ & $\begin{array}{l}-0.0407^{*} \\
(0.0232)\end{array}$ \\
\hline size2 & $\begin{array}{l}0.0280 \\
(0.0179)\end{array}$ & $\begin{array}{l}0.0154 \\
(0.0105)\end{array}$ & $\begin{array}{l}0.00347 \\
(0.00262)\end{array}$ & $\begin{array}{l}0.00347 \\
(0.00262)\end{array}$ & $\begin{array}{l}0.00349 \\
(0.00262)\end{array}$ & $\begin{array}{l}0.00259 \\
(0.00268)\end{array}$ \\
\hline exportint & $\begin{array}{l}-0.0222 \\
(0.206)\end{array}$ & $\begin{array}{l}-0.0237 \\
(0.115)\end{array}$ & $\begin{array}{l}0.000475 \\
(0.0188)\end{array}$ & $\begin{array}{l}0.000475 \\
(0.0188)\end{array}$ & $\begin{array}{l}0.000687 \\
(0.0188)\end{array}$ & $\begin{array}{l}-0.00980 \\
(0.0193)\end{array}$ \\
\hline newmarkets & $\begin{array}{l}-0.198 * * \\
(0.0782)\end{array}$ & $\begin{array}{l}-0.122 * * \\
(0.0535)\end{array}$ & $\begin{array}{l}-0.0220 * * \\
(0.0108)\end{array}$ & $\begin{array}{l}-0.0220 * * \\
(0.0108)\end{array}$ & $\begin{array}{l}-0.0220 * * \\
(0.0108)\end{array}$ & $\begin{array}{l}-0.0437 \text { *** } \\
(0.0114)\end{array}$ \\
\hline qualimprv & $\begin{array}{l}0.0481 \\
(0.0828)\end{array}$ & $\begin{array}{l}0.0286 \\
(0.0460)\end{array}$ & $\begin{array}{l}0.00658 \\
(0.00993)\end{array}$ & $\begin{array}{l}0.00658 \\
(0.00993)\end{array}$ & $\begin{array}{l}0.00655 \\
(0.00993)\end{array}$ & $\begin{array}{l}0.00232 \\
(0.00982)\end{array}$ \\
\hline partnership & $\begin{array}{l}0.134 * \\
(0.0710)\end{array}$ & $\begin{array}{l}0.0747 * \\
(0.0407)\end{array}$ & $\begin{array}{l}0.0168 * \\
(0.00944)\end{array}$ & $\begin{array}{l}0.0168^{*} \\
(0.00944)\end{array}$ & $\begin{array}{l}0.0168 * \\
(0.00944)\end{array}$ & $\begin{array}{l}0.00986 \\
(0.00960)\end{array}$ \\
\hline prodreplace & $\begin{array}{l}0.200^{* *} \\
(0.0822)\end{array}$ & $\begin{array}{l}0.110^{* *} \\
(0.0446)\end{array}$ & $\begin{array}{l}0.0233 * * \\
(0.00988)\end{array}$ & $\begin{array}{l}0.0233 * * \\
(0.00988)\end{array}$ & $\begin{array}{l}0.0233 * * \\
(0.00988)\end{array}$ & $\begin{array}{l}0.0250 * * \\
(0.00999)\end{array}$ \\
\hline marketthreat & $\begin{array}{l}-0.226^{* *} \\
(0.0913)\end{array}$ & $\begin{array}{l}-0.120 * * \\
(0.0495)\end{array}$ & $\begin{array}{l}-0.0264^{* *} \\
(0.0108)\end{array}$ & $\begin{array}{l}-0.0264 * * \\
(0.0108)\end{array}$ & $\begin{array}{l}-0.0263 * * \\
(0.0108)\end{array}$ & $\begin{array}{l}-0.0259^{* *} \\
(0.0108)\end{array}$ \\
\hline foreigncomp & $\begin{array}{l}-0.0801 \\
(0.0706)\end{array}$ & $\begin{array}{l}-0.0465 \\
(0.0390)\end{array}$ & $\begin{array}{l}-0.0106 \\
(0.00843)\end{array}$ & $\begin{array}{l}-0.0106 \\
(0.00843)\end{array}$ & $\begin{array}{l}-0.0105 \\
(0.00843)\end{array}$ & $\begin{array}{l}-0.00877 \\
(0.00858)\end{array}$ \\
\hline Constant & $\begin{array}{l}-1.574 * * * \\
(0.389)\end{array}$ & $\begin{array}{l}-0.932 * * * \\
(0.218)\end{array}$ & $\begin{array}{l}0.183 * * * \\
(0.0519)\end{array}$ & $\begin{array}{l}0.183^{* * * *} \\
(0.0519)\end{array}$ & $\begin{array}{l}0.183 * * * \\
(0.0519)\end{array}$ & $\begin{array}{l}0.174 * * * \\
(0.0527)\end{array}$ \\
\hline Sector dummies & Yes & Yes & Yes & Yes & Yes & Yes \\
\hline IV & No & Yes & Yes & Yes & Yes & Yes \\
\hline Observations & 1969 & 1969 & 1969 & 1969 & 1969 & 1969 \\
\hline$R$-squared & & & 0.056 & 0.056 & 0.056 & 0.027 \\
\hline Pseudo R2 & 0.0636 & & & & & \\
\hline log likelihood & -796.4 & -1700 & -738.5 & -738.5 & -738.5 & -768.2 \\
\hline Wald Chi2 & 113.4 & 767.6 & & & & \\
\hline Wald df & 22 & 45 & & & & \\
\hline Wald $p$ value & $<0.0001$ & $<0.0001$ & & & & \\
\hline Hansens J & & & 0.0435 & 0.0435 & 0.0435 & 21.79 \\
\hline$p$ value & & & 0.835 & 0.835 & 0.835 & 0.352 \\
\hline KP rk LM & & & 217.1 & 217.1 & 217.1 & 82.79 \\
\hline$p$ value & & & $<0.0001$ & $<0.0001$ & $<0.0001$ & $<0.0001$ \\
\hline KP rk Wald F & & & 143.6 & 143.6 & 143.6 & 3.961 \\
\hline
\end{tabular}

Coefficients with standard errors in parentheses. All standard errors are robust to heteroskedasticity

The variable measuring innovativeness (prodinno) in models (2)-(6) are instrumented with the R\&D intensity (rdInt) and the patenting behavior (patents) of the respective company. Respective first-stage results are available from the authors upon request. All models contain dummy variables controlling for 12 different sectors using two-digit Nace rev. 2 codes

$* * * p<0.01 ; * * p<0.05 ; * p<0.1$ 
Table 7 Estimations results to explain success in domestic public procurement. Alternative specification of innovation: innosuc

\begin{tabular}{|c|c|c|c|c|c|}
\hline $\begin{array}{l}\text { Dependent variable: Suc- } \\
\text { cess in public procurement }\end{array}$ & (1) & (2) & (3) & (4) & (5) \\
\hline VARIABLES & LOGIT & 2SLS & LIML & GMM & LEWBEL \\
\hline innosuc & $\begin{array}{l}0.240 * * * \\
(0.0571)\end{array}$ & $\begin{array}{l}0.0475 * * \\
(0.0222)\end{array}$ & $\begin{array}{l}0.0475^{* *} \\
(0.0222)\end{array}$ & $\begin{array}{l}0.0473 * * \\
(0.0222)\end{array}$ & $\begin{array}{l}0.0501 * * * \\
(0.0143)\end{array}$ \\
\hline stand & $\begin{array}{l}0.639 * * * \\
(0.236)\end{array}$ & $\begin{array}{l}0.0862 * * \\
(0.0371)\end{array}$ & $\begin{array}{l}0.0862 * * \\
(0.0371)\end{array}$ & $\begin{array}{l}0.0863 * * \\
(0.0371)\end{array}$ & $\begin{array}{l}0.0861 * * \\
(0.0369)\end{array}$ \\
\hline size & $\begin{array}{l}-0.320 * * \\
(0.159)\end{array}$ & $\begin{array}{l}-0.0383 * \\
(0.0230)\end{array}$ & $\begin{array}{l}-0.0383^{*} \\
(0.0230)\end{array}$ & $\begin{array}{l}-0.0385^{*} \\
(0.0230)\end{array}$ & $\begin{array}{l}-0.0380^{*} \\
(0.0227)\end{array}$ \\
\hline size 2 & $\begin{array}{l}0.0237 \\
(0.0177)\end{array}$ & $\begin{array}{l}0.00258 \\
(0.00270)\end{array}$ & $\begin{array}{l}0.00258 \\
(0.00270)\end{array}$ & $\begin{array}{l}0.00260 \\
(0.00270)\end{array}$ & $\begin{array}{l}0.00250 \\
(0.00260)\end{array}$ \\
\hline exportint & $\begin{array}{l}0.0105 \\
(0.158)\end{array}$ & $\begin{array}{l}-0.00171 \\
(0.0217)\end{array}$ & $\begin{array}{l}-0.00171 \\
(0.0217)\end{array}$ & $\begin{array}{l}-0.00146 \\
(0.0217)\end{array}$ & $\begin{array}{l}-0.00218 \\
(0.0215)\end{array}$ \\
\hline newmarkets & $\begin{array}{l}-0.139 * \\
(0.0772)\end{array}$ & $\begin{array}{l}-0.0204^{*} \\
(0.0105)\end{array}$ & $\begin{array}{l}-0.0204^{*} \\
(0.0105)\end{array}$ & $\begin{array}{l}-0.0204^{*} \\
(0.0105)\end{array}$ & $\begin{array}{l}-0.0211 * * \\
(0.00937)\end{array}$ \\
\hline qualimprv & $\begin{array}{l}0.0455 \\
(0.0823)\end{array}$ & $\begin{array}{l}0.00399 \\
(0.0103)\end{array}$ & $\begin{array}{l}0.00399 \\
(0.0103)\end{array}$ & $\begin{array}{l}0.00396 \\
(0.0103)\end{array}$ & $\begin{array}{l}0.00370 \\
(0.00985)\end{array}$ \\
\hline partnership & $\begin{array}{l}0.132 * \\
(0.0716)\end{array}$ & $\begin{array}{l}0.0133 \\
(0.0100)\end{array}$ & $\begin{array}{l}0.0133 \\
(0.0100)\end{array}$ & $\begin{array}{l}0.0134 \\
(0.0100)\end{array}$ & $\begin{array}{l}0.0129 \\
(0.00960)\end{array}$ \\
\hline prodreplace & $\begin{array}{l}0.215^{* * * *} \\
(0.0812)\end{array}$ & $\begin{array}{l}0.0267 * * * \\
(0.0101)\end{array}$ & $\begin{array}{l}0.0267 * * * \\
(0.0101)\end{array}$ & $\begin{array}{l}0.0267 * * * \\
(0.0101)\end{array}$ & $\begin{array}{l}0.0269 * * * \\
(0.00983)\end{array}$ \\
\hline marketthreat & $\begin{array}{l}-0.237 * * * \\
(0.0901)\end{array}$ & $\begin{array}{l}-0.0278 * * \\
(0.0108)\end{array}$ & $\begin{array}{l}-0.0278 * * \\
(0.0108)\end{array}$ & $\begin{array}{l}-0.0278 * * \\
(0.0108)\end{array}$ & $\begin{array}{l}-0.0279 * * * \\
(0.0108)\end{array}$ \\
\hline foreigncomp & $\begin{array}{l}-0.0728 \\
(0.0699)\end{array}$ & $\begin{array}{l}-0.00871 \\
(0.00857)\end{array}$ & $\begin{array}{l}-0.00871 \\
(0.00857)\end{array}$ & $\begin{array}{l}-0.00866 \\
(0.00857)\end{array}$ & $\begin{array}{l}-0.00854 \\
(0.00852)\end{array}$ \\
\hline Constant & $\begin{array}{l}-1.566^{* * * *} \\
(0.387)\end{array}$ & $\begin{array}{l}0.179 * * * \\
(0.0524)\end{array}$ & $\begin{array}{l}0.179 * * * \\
(0.0524)\end{array}$ & $\begin{array}{l}0.180 * * * \\
(0.0524)\end{array}$ & $\begin{array}{l}0.179 * * * \\
(0.0522)\end{array}$ \\
\hline Sector dummies & Yes & Yes & Yes & Yes & Yes \\
\hline IV & No & Yes & Yes & Yes & Yes \\
\hline Observations & 1969 & 1969 & 1969 & 1969 & 1969 \\
\hline R-squared & & 0.046 & 0.046 & 0.046 & 0.045 \\
\hline Pseudo R2 & 0.0538 & & & & \\
\hline log likelihood & -804.8 & -748.9 & -748.9 & -748.8 & -749.6 \\
\hline Wald Chi2 & 99.28 & & & & \\
\hline Wald df & 22 & & & & \\
\hline Wald $p$ value & $<0.0001$ & & & & \\
\hline Hansens J & & 0.0478 & 0.0478 & 0.0478 & 17.11 \\
\hline$p$ value & & 0.827 & 0.827 & 0.827 & 0.646 \\
\hline KP rk LM & & 175.1 & 175.1 & 175.1 & 196.2 \\
\hline$p$ value & & $<0.0001$ & $<0.0001$ & $<0.0001$ & $<0.0001$ \\
\hline KP rk Wald F & & 113.6 & 113.6 & 113.6 & 27.03 \\
\hline
\end{tabular}

Coefficients with standard errors in parentheses. All standard errors are robust to heteroskedasticity

The variable measuring innovativeness (innosuc) in models (2)-(6) are instrumented with the R\&D intensity (rdInt) and the patenting behavior (patents) of the respective company. Respective first-stage results are available from the authors upon request. All models contain dummy variables controlling for 12 different sectors using two-digit Nace rev. 2 codes

$* * * p<0.01 ; * * p<0.05 ; * p<0.1$ 
Table 8 Results of the main independent variables after matching

\begin{tabular}{|c|c|c|c|c|c|c|}
\hline \multirow[t]{3}{*}{ Treatment variable } & \multicolumn{3}{|c|}{ Product innovation (pdpp) } & \multicolumn{3}{|c|}{$\begin{array}{l}\text { Engagement in standardization } \\
\text { (stand) }\end{array}$} \\
\hline & \multicolumn{2}{|l|}{ Mean } & \multirow[t]{2}{*}{$p$ value of t-test } & \multicolumn{2}{|l|}{ Mean } & \multirow[t]{2}{*}{$p$ value of t-test } \\
\hline & Treated & Control & & Treated & Control & \\
\hline bade $^{a}$ & 0.208 & 0.074 & $<0.001$ & 0.236 & 0.142 & 0.021 \\
\hline size & 4.258 & 4.248 & 0.895 & 5.601 & 5.446 & 0.403 \\
\hline size 2 & 20.775 & 20.355 & 0.577 & 33.736 & 32.084 & 0.444 \\
\hline exportint & 0.308 & 0.359 & 0.156 & 0.44 & 0.456 & 0.818 \\
\hline newmarkets & 1.847 & 1.86 & 0.798 & 2.168 & 2.16 & 0.936 \\
\hline qualimprv & 2.55 & 2.582 & 0.361 & 2.471 & 2.471 & 0.995 \\
\hline partnership & 1.125 & 1.088 & 0.437 & 1.107 & 1.059 & 0.648 \\
\hline prodreplace & 1.642 & 1.644 & 0.982 & 1.6 & 1.635 & 0.734 \\
\hline marketthreat & 1.43 & 1.398 & 0.415 & 1.271 & 1.27 & 0.99 \\
\hline foreigncomp & 1.627 & 1.594 & 0.495 & 1.879 & 1.839 & 0.703 \\
\hline edbls, textiles, wood & 0.203 & 0.22 & 0.413 & 0.071 & 0.087 & 0.638 \\
\hline ref. petrol, coke & 0.008 & 0.008 & 0.94 & 0.014 & 0.017 & 0.854 \\
\hline chemicals & 0.081 & 0.07 & 0.422 & 0.064 & 0.062 & 0.936 \\
\hline pharmaceutical & 0.018 & 0.018 & 0.918 & 0.029 & 0.036 & 0.74 \\
\hline rubber, plastic, metal & 0.157 & 0.189 & 0.101 & 0.15 & 0.179 & 0.522 \\
\hline fabr. metal & 0.073 & 0.074 & 0.936 & 0.129 & 0.111 & 0.653 \\
\hline comp., elec., optic. & 0.117 & 0.109 & 0.616 & 0.121 & 0.118 & 0.922 \\
\hline elec., mach., vehic. & 0.261 & 0.247 & 0.509 & 0.336 & 0.338 & 0.969 \\
\hline wtr., rail., spce trnsp. & 0.013 & 0.01 & 0.644 & 0.036 & 0.014 & 0.246 \\
\hline furniture & 0.026 & 0.018 & 0.3 & 0.014 & 0.015 & 0.936 \\
\hline other manuf., Medical, dental & 0.036 & 0.032 & 0.606 & 0.021 & 0.018 & 0.833 \\
\hline mach. repair, instlln. & 0.007 & 0.006 & 0.846 & 0.014 & 0.006 & 0.511 \\
\hline
\end{tabular}

${ }^{a}$ t-Tests are based on bootstrapped standard errors with 100 replications

\section{References}

Appelt, S., \& Galindo-Rueda, F. (2016). Measuring the Link between public procurement and innovation. OECD Science, Technology and Industry Working Papers, 2016/03. Paris: OECD Publishing. http:// dx.doi.org/10.1787/5jlvc7s11w7h-en.

Artz, K. W., Norman, P. M., Hatfield, D. E., \& Cardinal, L. B. (2010). A longitudinal study of the impact of $\mathrm{R} \& \mathrm{D}$, patents, and product innovation on firm performance. Journal of Product Innovation Management, 27(5), 725-740.

Arvidsson, A., \& Stage, J. (2012). Technology-neutral green procurement in practice-An example from Swedish waste management. Waste Management and Research, 30(5), 519-523.

Aschhoff, B., \& Sofka, W. (2009). Innovation on demand-Can public procurement drive market success of innovations? Research Policy, 38, 1235-1247. https://doi.org/10.1016/j.respol.2009.06.011.

Baum, C. F., \& Schaffer, M. E. (2012). ivreg2h: Stata module to perform instrumental variables estimation using heteroskedasticity-based instruments. Retrieved October 3, 2018 from http://ideas.repec.org/c/ boc/bocode/s457555.html.

Besanko, D. (1987). Performance versus design standards in the regulation of pollution. Journal of Public Economics, 34, 19-44. 
Blind, K. (2006). Explanatory factors for participation in formal standardisation processes: Empirical evidence at company level. Economics of Innovation and New Technology, 15(2), 157-170. https://doi. org/10.1080/10438590500143970.

Blind, K. (2007). Using standards in public procurement processes to promote innovation-A conceptual framework. In J. Gröndahl, K. Jakobs, \& A. Zachariadis (Eds.), EURAS proceedings (Aachener Beiträge zur Informatik, Band 39) (pp. 11-20). Aachen: Wissenschaftsverlag Mainz.

Blind, K. (2008). Driving innovation-Standards and public procurement. ISO Focus, 5(9), 44-45.

Blind, K., \& Gauch, S. (2009). Research and standardisation in nanotechnology: Evidence from Germany. The Journal of Technology Transfer, 34(3), 320-342. https://doi.org/10.1007/s10961-008-9089-8.

Blind, K., Gauch, S., \& Hawkins, R. (2010). How stakeholders view the impacts of international ICT standards. Telecommunications Policy, 34(3), 162-174. https://doi.org/10.1016/j.telpol.2009.11.016.

Blind, K., \& Mangelsdorf, A. (2013). Alliance formation of SMEs: Empirical evidence from standardization committees. IEEE Transactions on Engineering Management, 60(1), 148-156. https://doi. org/10.1109/TEM.2012.2192935.

Blind, K., \& Mangelsdorf, A. (2016). Motives to standardize: Empirical evidence from Germany. Technovation, 48-49, 13-24. https://doi.org/10.1016/j.technovation.2016.01.001.

Blind, K., Rauber, J., \& Müller, J.-A. (2014). German Standardization Panel (DNP) Research, politics and promotion of standardization-Report on indicators 2014. German Society for the Promotion of Research on Standardization e.V, Berlin.

Bloom, N., \& Van Reenen, J. (2002). Patents, real options and firm performance. The Economic Journal, 112(478), C97-C116.

BMBF. (2006). Hightech-Strategie für Deutschland. Berlin: Bundesministerium für Bildung und Forschung (BMBF).

BMBF. (2010). Hightech-Strategie 2020 für Deutschland. Bonn: Bundesministerium für Bildung und Forschung (BMBF).

BMBF. (2014). Die neue Hightech-Strategie - Innovationen für Deutschland. Berlin: Bundesministerium für Bildung und Forschung (BMBF).

Büthe, T., \& Mattli, W. (2011). The new global rulers: The privatization of regulation in the world economy. Princeton: Princeton University Press.

Cabral, L., \& Salant, D. (2014). Evolving technologies and standards regulation. International Journal of Industrial Organization, 36, 48-56.

Caliendo, M., \& Kopeinig, S. (2008). Some practical guidance for the implementation of propensity score matching. Journal of economic surveys, 22(1), 31-72.

Chesbrough, H. (2004). Managing open innovation. Research-Technology Management, 47, 23-26.

Czarnitzki, D., \& Toole, A. A. (2011). Patent protection, market uncertainty, and R\&D investment. Review of Economics and Statistics, 93(1), 147-159.

Dale, L., \& Bryson, J. (2012). Climate market accelerator-Pilot study: Public procurement and innovation final report. Birmingham: University of Birmingham.

David, P. A. (1995). Standardization policies for network technologies: The flux between freedom and order revisited. In R. Hawkins, R. Mansell, \& J. Skea (Eds.), Standards, innovation and competitiveness: The politics and economics of standards in natural and technical environments (pp. 15-35). Cheltenham: Edward Elgar.

David, P. A., \& Greenstein, S. M. (1990). The economics of compatibility standards: An introduction to recent research. Economics of Innovation and New Technology, 1(1/2), 3-41.

DIN. (2013). Annual report. Berlin: Deutsches Institut für Normung.

DIN. (2014). Standards in public purchasing - A guide to the role and use of technical standards in public procurement. Berlin.

EC. (2004). Directive 2004/17/EC of the European Parliament and of the Council of 31 March 2004-Coordinating the procurement procedures of entities operating in the water, energy, transport and postal services sectors.

EC. (2007). Pre-commercial procurement: Driving innovation to ensure sustainable high quality public services in Europe. Brussels: European Commission.

EC. (2008). Towards an increased contribution from standardisation to innovation in Europe: Commission of the European Communities. Brussels: European Commission.

EC. (2010). Europe 2020 flagship initiative innovation union. Brussels: European Commission.

EC. (2011). Impact assessment accompanying document to the proposal for a regulation of the European Parliament and of the council on European Standardisation. Brussels: European Commission.

EC. (2014). Directive 2014/24/EU of the European parliament and of the council of 26 February 2014 on public procurement and repealing directive 2004/18/EC. Brussels: European Commission. 
Edler, J. (2016). The impact of policy measures to stimulate private demand for innovation. In J. Edler, P. Cunningham, A. Gök, \& P. Shapira (Eds.), Handbook of innovation policy impact (pp. 318-354). Cheltenham: Edward Elgar.

Edler, J., Georghiou, L., Blind, K., \& Uyarra, E. (2014). Evaluating the demand side: New challenges for evaluation. Research Evaluation, 21, 33-47.

Edquist, C., \& Zabala-Iturriagagoitia, J. M. (2012). Public procurement for innovation as mission-oriented innovation policy. Research Policy, 41(10), 1757-1769. https://doi.org/10.1016/j.respol.2012.04.022.

Erridge, A., \& Nondi, R. (1994). Public procurement, competition and partnership. European Journal of Purchasing \& Supply Management, 1(3), 169-179. https://doi.org/10.1016/0969-7012(94)90006-X.

Europe Innova. (2008). STandards in European Public Procurement leading to INnovation (STEPPIN). Directorate General Enterprise and Industry. Brussels: European Commission.

FreshMinds. (2008). Evaluating SME Experiences of Government Procurement. British Private Equity and Venture Capital Association (BVCA), Federation of Small Businesses (FSB), Confederation of British Industry (CBI) and Fresh Minds. October 2008. ISBN: 978090677986 6. Retrieved 14 January 2016 from http://www.fsb.org.uk/LegacySitePath/policy/images/12615\%20fsb\%20procurement.pdf.

Georghiou, L. (2007). Demanding innovation: Lead markets, public procurement and innovation. London: National Endowment for Science, Technology, and the Arts (NESTA).

Georghiou, L., Edler, J., Uyarra, E., \& Yeow, J. (2014). Policy instruments for public procurement of innovation: Choice, design and assessment. Technological Forecasting and Social Change, 86, 1-12. https ://doi.org/10.1016/j.techfore.2013.09.018.

Geroski, P. A. (1990). Procurement policy as a tool of industrial policy. International Review of Applied Economics, 4(2), 182-198. https://doi.org/10.1080/758523673.

Ghisetti, C. (2017). Demand-pull and environmental innovations: Estimating the effects of innovative public procurement. Technological Forecasting and Social Change, 125, 178-187. https://doi. org/10.1016/j.techfore.2017.07.020.

Ghosh, R. A. (2005). An Economic Basis for Open Standards, Deliverable of the FLOSSPOLS project, funded under the Sixth Framework Programme of the European Union, managed by the eGovernment Unit of the European Commission's DG Information Society. Maastricht.

Griliches, Z. (1986). Productivity, R\&D, and the basic research at the firm level in the 1970's. American Economic Review, American Economic Association, 76(1), 141-154.

Guerzoni, M., \& Raiteri, E. (2015). Demand-side vs. supply-side technology policies: Hidden treatment and new empirical evidence on the policy mix. Research Policy, 44, 726-747.

Gupta, A. K., \& Lad, L. J. (1983). Industry self-regulation: An economic, organizational, and political analysis. Academy of Management Review, 8(3), 416-425.

Hall, L. A., \& Bagchi-Sen, S. (2002). A study of R\&D, innovation, and business performance in the Canadian biotechnology industry. Technovation, 22(4), 231-244.

Heckman, J. J. (1978). Dummy endogenous variables in a simultaneous equation system. Econometrica, 46(6), 931-959.

Hommen, L., \& Rolfstam, M. (2009). Public procurement and innovation: Towards a taxonomy. Journal of Public Procurement, 9(1), 17-56.

Hueth, B., \& Melkonyan, T. (2009). Standards and the regulation of environmental risk. Journal of Regulatory Economics, 36(3), 219-246.

Karjalainen, K., \& Kemppainen, K. (2008). The involvement of small- and medium-sized enterprises in public procurement: Impact of resource perceptions, electronic systems and enterprise size. Journal of Purchasing \& Supply Management, 14, 230-240. https://doi.org/10.1016/j.pursu p.2008.08.003.

Knutsson, H., \& Thomasson, A. (2014). Innovation in the Public Procurement Process: A study of the creation of innovation-friendly public procurement. Public Management Review, 16(2), 242-255. https://doi.org/10.1080/14719037.2013.806574.

Koch, C., \& Jacobsen, K. (2014). Computerized information standards enabling innovation in public procurement of buildings. Human interface and the management of information. Information and knowledge design and evaluation. In 16th International Conference, HCI International 2014. Proceedings: LNCS 8521 (pp. 373-383).

Kok, W. (2004). Facing the challenge. The Lisbon strategy for growth and employment. Office for Official Publications of the European Communities, Luxembourg.

Kutlina-Dimitrova, Z., \& Lakatos, C. (2016). Determinants of direct cross-border public procurement in EU Member States. Review of World Economics, 152(3), 501-528.

Laursen, K., \& Salter, A. (2006). Open for innovation: The role of openness in explaining innovation performance among UK manufacturing firms. Strategic Management Journal, 27(2), 131-150. 
Leuven, E., \& Sianesi, B. (2003). PSMATCH2: Stata module to perform full Mahalanobis and propensity score matching, common support graphing, and covariate imbalance testing. Retrieved December 17, 2018 from http://ideas.repec.org/c/boc/bocode/s432001.html.

Lewbel, A. (2012). Using heteroscedasticity to identify and estimate mismeasured and endogenous regressor models. Journal of Business \& Economic Statistics, 30(1), 67-80.

Loader, K. (2011). Are public sector procurement models and practices hindering small and medium suppliers? Public Money \& Management, 31, 287-294. https://doi.org/10.1080/09540962.2011.58624 2.

Loader, K. (2013). Is public procurement a successful small business support policy? A review of the evidence. Environment and Planning C-Government and Policy, 31, 39-55. https://doi. org/10.1068/c1213b.

Loader, K. (2015). SME suppliers and the challenge of public procurement: Evidence revealed by a UK government online feedback facility. Journal of Purchasing \& Supply Management, 21(2), 103-112. https://doi.org/10.1016/j.pursup.2014.12.003.

London Economics, ECORYS, \& PWC. (2011). Public procurement in Europe-Cost and effectiveness. A study on procurement regulation. Prepared for the European Commission.

Lorenz, O., Lange, M., Rahmann, T., Blind, K., Weber, M., \& Krohn, W. (2009). »Einkäufer Staat« als Innovationstreiber. Entwicklungspotenziale und Handlungsnotwendigkeiten für eine innovativere Beschaffung im öffentlichen Auftragswesen Deutschlands. Berlin: Wegweiser, TU Berlin und Orrick.

Malara, M., \& Mazurkiewicz, M. (2012). Modelling the determinants of winning in public tendering procedures based on the activity of a selected company. Operations Research and Decisions, 1, 51-62. https://doi.org/10.5277/ord120103.

Maxwell, J. W. (1998). Minimum quality standards as a barrier to innovation. Economics Letters, 58(3), 355-360.

Michaelis, C., McGuire, M., \& Ferguson, L. (2003). SBS diversity in public sector procurement survey. Birmingham: Databuild Research and Solutions.

Neij, L. (2001). Methods of evaluating market transformation programmes: Experience in Sweden. Energy Policy, 29, 67-79.

O'Brien, R. M. (2007). A caution regarding rules of thumb for variance inflation factors. Quality \& Quantity, 41(5), 673-690. https://doi.org/10.1007/s11135-006-9018-6.

OECD. (2009). Sustainable manufacturing and eco-innovation: Towards a green economy. Paris: Organization for Economic Co-operation and Development.

OECD. (2011). Demand-side innovation policies. Paris: Organization for Economic Co-operation and Development Publishing.

OECD. (2015). Strategic public procurement. In Government at a Glance 2015. Paris: OECD Publishing. http://dx.doi.org/10.1787/gov_glance-2015-43-en.

OECD. (2018). Germany. In SMEs in public procurement: practices and strategies for shared benefits. Paris: OECD Publishing. https://doi.org/10.1787/9789264307476-19-en.

Palmberg, C. (2002). Technological systems and competent procurers-The transformation of Nokia and the Finnish telecom industry revisited? Telecommunications Policy, 26(2002), 129-148.

Pickernell, D., Kay, A., Packham, G., \& Miller, C. (2011). Competing agendas in public procurement: an empirical analysis of opportunities and limits in the UK for SMEs. Environment and Planning C-Government and Policy, 29, 641-658. https://doi.org/10.1068/c10164b.

Procurement Innovation Group. (2009). Using public procurement to stimulate innovation and SME access to public contracts (T. a. E. Department of Enterprise, Trans.).

Putten, M. V. (2012). Leading public innovation procurement. Paper presented at the 5th international public procurement conference, Seattle, USA.

Rainville, A. (2016). From whence the knowledge came: Heterogeneity of innovation procurement across Europe. Journal of Public Procurement, 16(4), 463-504.

Rainville, A., Hawkins, R., \& Bergerson, J. (2014). Building consensus in life cycle assessment: The potential for a Canadian product category rules standard to enhance credibility in greenhouse gas emissions estimates for Alberta's oil sands. Journal of Cleaner Production. https://doi.org/10.1016/j.jclep ro.2014.06.067.

Rammer, C., Czarnitzki, D., \& Spielkamp, A. (2009). Innovation success of non-R\&D-performers: Substituting technology by management in SMEs. Small Business Economics, 33(1), 35-58.

Rigby, J., Boekholt, P., Semple, A., Deuten, J., Apostol, R., Corvers, S., et al. (2012). Feasibility study on future EU support to public procurement of innovative solutions: Obtaining Evidence for a Full Scheme. Manchester, UK: University of Manchester Technopolis Group, ICLEI-Local Governments for Sustainability and Corvers Consulting. 
Rolfstam, M. (2013). Public procurement and innovation: The role of institutions. Cheltenham: Edward Elgar.

Rolfstam, M. (2014). Public procurement as a means to stimulate innovation for a better world: A matter of knowledge management. Available at SSRN: https://ssrn.com/abstract=2409631.

Shingal, A. (2015). Econometric analyses of home bias in government procurement. Review of International Economics, 23(1), 188-219. https://doi.org/10.1111/roie.12164.

Staffelt, D. (2004). Antwort der Bundesregierung auf die Anfrage des Abgeordneten Wanderwitz (pp. 17-19). In Deutscher Bundestag (Ed.) Drucksache 15/3648. Berlin.

Stake, J. (2017). Evaluating quality or lowest price: Consequences for small and medium-sized enterprises in public procurement. Journal of Technology Transfer, 42, 1143-1169. https://doi.org/10.1007/s1096 1-016-9477-4.

Stock, J., Yogo, M., \& Andrews, D. W. (2005). Testing for weak instruments in Linear IV regression. Cambridge: Cambridge University Press.

Tabish, S. Z. S., \& Jha, K. N. (2011). Identification and evaluation of success factors for public construction projects. Construction Management and Economics, 29(8), 809-823. https://doi.org/10.1080/01446 193.2011.611152.

Thai, K. V. (2009). International public procurement: Concepts and practices. In K. V. Thai (Ed.), International handbook of public procurement (pp. 1-24). Boca Raton: CRC Press/Taylor \& Francis Group.

Trionfetti, F. (2000). Discriminatory public procurement and international trade. The World Economy, 23, $57-76$.

Uyarra, E. (2016). The impact of public procurement of innovation. J. Edler, P. Cunningham, A. Gök, \& P. Shapira (Eds.), Handbook of innovation policy impact (pp. 355-381). Cheltenham: Edward Elgar.

Uyarra, E., Edler, J., Garcia-Estevez, J., Georghiou, L., \& Yeow, J. (2014). Barriers to innovation through public procurement: A supplier perspective. Technovation, 34(10), 631-645. https://doi.org/10.1016/j. technovation.2014.04.003.

Vecchiato, R., \& Roveda, C. (2014). Foresight for public procurement and regional innovation policy: The case of Lombardy. Research Policy, 43, 438-450. https://doi.org/10.1016/j.respol.2013.11.003.

Wakke, P., Blind, K., \& De Vries, H. (2015). Driving factors for service providers to participate in standardization: Insights from the Netherlands. Industry \& Innovation, 22(4), 299-320. https://doi. org/10.1080/13662716.2015.1049865.

Wakke, P., Blind, K., \& Ramel, F. (2016). The impact of participation within formal standardization on firm performance. Journal of Productivity Analysis, 45(3), 317-330. https://doi.org/10.1007/s1112 3-016-0465-3.

Wegweiser, TU Berlin, \& Hölters \& Elsing. (2009). The “purchasing state” as a driver of innovation. Berlin: Wegweiser GmbH Berlin Research \& Strategy, Technische Universität Berlin, Hölters \& Elsing.

Weiss, M. B. H., \& Sirbu, M. (1990). Technological choice in voluntary standards committees: An empirical analysis. Economics of Innovation and New Technology, 1(1-2), 111-133. https://doi. org/10.1080/10438599000000007.

Wooldridge, J. M. (2010). Econometric analysis of cross section and panel data. Cambridge: MIT Press.

Yeow, J., \& Edler, J. (2012). Innovation procurement as projects. Journal of Public Procurement, 12(4), 472-504.

Publisher's Note Springer Nature remains neutral with regard to jurisdictional claims in published maps and institutional affiliations. 